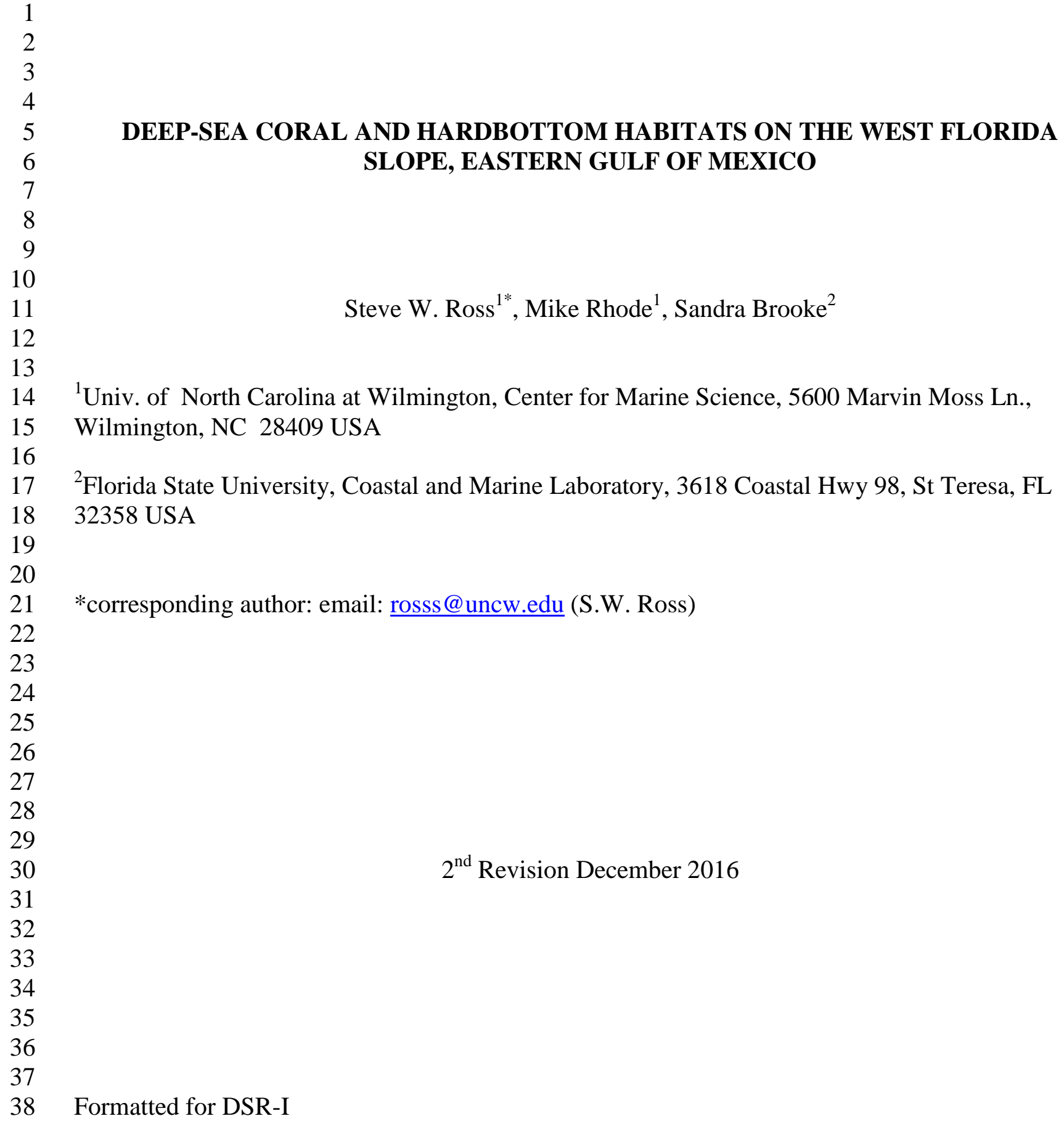

${ }^{1}$ Univ. of North Carolina at Wilmington, Center for Marine Science, 5600 Marvin Moss Ln., Wilmington, NC 28409 USA

Steve W. Ross ${ }^{1 *}$, Mike Rhode $^{1}$, Sandra Brooke $^{2}$

\section{DEEP-SEA CORAL AND HARDBOTTOM HABITATS ON THE WEST FLORIDA SLOPE, EASTERN GULF OF MEXICO}

38 Formatted for DSR-I

20

39 


\section{Abstract}

Until recently, benthic habitats dominated by deep-sea corals (DSC) appeared to be less extensive on the slope of the Gulf of Mexico (GOM) than in the northeast Atlantic Ocean or off the southeastern US. There are relatively few bioherms (i.e., coral-built mounds) in the northern GOM, and most DSCs are attached to existing hard substrata (e.g., authigenically formed carbonate). The primary structure-forming, DSC in the GOM is Lophelia pertusa, but structure is also provided by other living and dead scleractinians, antipatharians (black corals), octocorals (gorgonians, soft corals), hydrocorals and sponges, as well as abundant rocky substrata. The best development of DSCs in the GOM was previously documented within Viosca Knoll oil and gas lease blocks 826 and 862/906 (north-central GOM) and on the Campeche Bank (southern GOM in Mexican waters). This paper documents extensive deep reef ecosystems composed of DSC and rocky hard-bottom recently surveyed on the West Florida Slope (WFS, eastern GOM) during six research cruises (2008-2012). Using multibeam sonar, CTD casts, and video from underwater vehicles, we describe the physical and oceanographic characteristics of these deep reefs and provide size or area estimates of deep coral and hardground habitats. The multibeam sonar analyses revealed hundreds of mounds and ridges, some of which were subsequently surveyed using underwater vehicles. Mounds and ridges in $<525 \mathrm{~m}$ depths were usually capped with living coral colonies, dominated by L. pertusa. An extensive rocky scarp, running roughly north-south for at least $229 \mathrm{~km}$, supported lower abundances of scleractinian corals than the mounds and ridges, despite an abundance of settlement substrata. Areal comparisons suggested that the WFS may exceed other parts of the GOM slope in extent of living deep coral coverage and other deep-reef habitat (dead coral and rock). The complex WFS region warrants additional studies to better understand the influences of oceanography and geology on the occurrence of DSC and associated organisms. Protection measures are being considered to ensure the long-term integrity of this diverse ecosystem.

Keywords: Gulf of Mexico; West Florida slope; deep-sea corals; deep reefs; Lophelia pertusa; habitat mapping; Loop Current 


\section{Introduction}

Until recently, benthic habitats dominated by deep-sea corals (DSC) appeared to be more scattered and less extensive in the Gulf of Mexico (GOM) (Brooke and Schroeder, 2007; Schroeder and Brooke, 2011) than on the slopes of the northeastern Atlantic Ocean (Hall-Spencer et al., 2011) or off the southeastern United States (SEUS) (Ross and Nizinski, 2007; Reed et al., 2013). In contrast with other regions of the North Atlantic, relatively few coral bioherms (elevations mostly created by successive coral growth, senescence and sedimentation) were known from the GOM slope, although extensive cold-water coral mounds were recently described from the Campeche Bank in the southern GOM (Hebbeln et al., 2014). Instead of building mounds, GOM DSCs were usually observed attached to abundant exposed hard substrata (Brooke and Schroeder, 2007), mostly authigenic carbonate blocks on the north-central GOM slope (Cordes et al., 2008; Schroeder and Brooke, 2011) and emergent carbonate and phosphorite hardgrounds on the slope of the eastern GOM (Brooks and Holmes, 2011). The main structure-forming DSC in the GOM is the branching scleractinian Lophelia pertusa, but complex structure is also provided by other living and dead scleractinians (e.g., Madrepora oculata, Enallopsammia profunda), antipatharians (e.g., Leiopathes sp.), octocorals (e.g., Keratoisis flexibilis, Callogorgia americana), hydrocorals (e.g., Stylaster sp.) and sponges, as well as the non-living rocky substrata (Schroeder and Brooke, 2011). Whether composed mostly of DSC or rock, collectively these complex deep reefs sustain similar ecological functions as shallow reefs, providing structure for the development of diverse benthic communities (Roberts et al., 2009; Lessard-Pilon et al., 2010). Over the last decade research programs directed toward DSC ecosystems in the GOM indicated that DSC reefs are most abundant in 300 to about $600 \mathrm{~m}$ depths and support distinct communities (Continental Shelf Associates, 2007; Cordes et al., 2008; Ross et al., 2012; Brooks et al., 2016).

GOM oil and gas lease blocks Viosca Knoll 826 (VK826, 415-480 m depths) and Viosca Knoll 92 862/906 (VK862/906, 310-440 m depths) in the north-central GOM, approximately $37 \mathrm{~km}$ apart 93 (Fig. 1), were previously reported to exhibit the most extensive DSC accumulations in the GOM 94 (Schroeder and Brooke, 2011). These sites are characterized by L. pertusa bioherms and carbonate 95 blocks colonized by corals and sponges, interspersed with shell hash, coral rubble and soft 96 sediments (Schroeder et al., 2005; Brooke and Schroeder, 2007; Continental Shelf Associates, 2007;

97 Davies et al., 2010). Based on several years of video surveys at the VK sites, we conservatively 

$\left(4,000,000 \mathrm{~m}^{2}\right.$ or $\left.40 \mathrm{~km}^{2}\right)$ of coral habitat (Hebbeln et al., 2014).

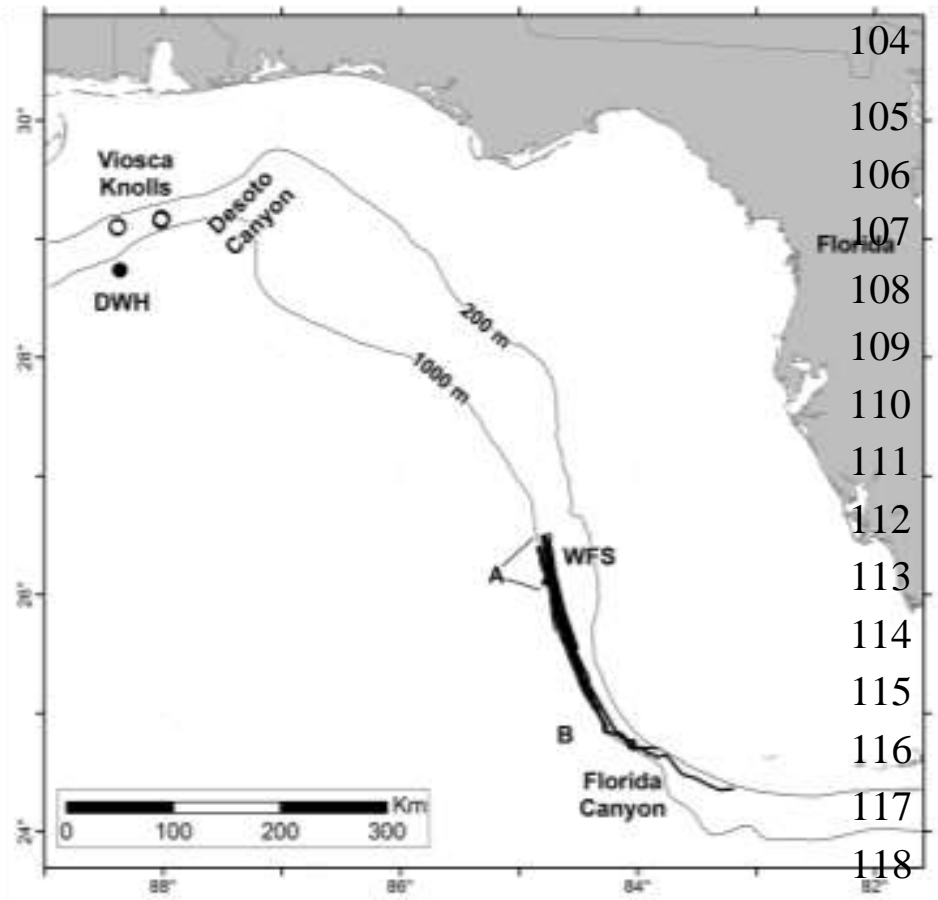

119

estimated (not previously published) the areas most heavily covered by DSC (living and dead) and rocky bottom to be about $412,500 \mathrm{~m}^{2}\left(0.413 \mathrm{~km}^{2}\right)$ at VK826 and about $562,500 \mathrm{~m}^{2}\left(0.563 \mathrm{~km}^{2}\right)$ at VK862/906 (Supplemental Fig. 1), but note that these estimates include some non-reef, soft-bottom habitat that is not separable at this scale. A newly discovered DSC region on the Campeche Bank, dominated by E. profunda and L. pertusa, reportedly surpasses the VK region in aerial extent

Figure 1. North-central and eastern Gulf of Mexico illustrating locations of the two Viosca Knoll deep reef sites, the DeepWater Horizon (DWH) well site, and the West Florida Slope (WFS) study area. Area A at the north end of the WFS study area was mapped with multibeam sonar by the NOAA ships Nancy Foster and Okeanos Explorer, was surveyed by several underwater vehicles, and is presented in greater detail in this paper. The strips (B) south of A were mapped by the M/V Lost Coast Explorer and the Okeanos Explorer.

This paper describes extensive areas of hard substrata and DSC, some recently discovered, on the West Florida Slope (WFS) in the eastern GOM and provides the oceanographic and geological context for these sites. Associated fauna will not be described except for major sessile species which contribute to benthic habitat structure. The midpoint of this study area is about 478 and 460

$125 \mathrm{~km}$ southeast of the VK deep reefs and the Deep-Water Horizon oil spill site, respectively (Fig. 1), and about $362 \mathrm{~km}$ northeast of the Campeche Bank deep coral mounds. Numerous small topographic highs with stands of mostly dead L. pertusa were described previously for part of the

128 WFS area (Newton et al., 1987; Reed et al., 2006; Hübscher et al., 2010). Recent multibeam sonar surveys of the WFS and subsequent visual surveys revealed widespread living coral colonies

130 capping large ridges and numerous putative DSC bioherms. The living DSC and complex habitat in this area is perhaps the most extensive in the GOM and may represent an important bridge for DSC 
132 communities between the Caribbean, the north-central GOM, and the rest of the North Atlantic.

133 Regardless of the area's role in connectivity, the WFS is an important reservoir of upper slope

134 biodiversity.

135

\section{Methods}

\subsection{Research Cruises}

139 Six research cruises provided data for the WFS region. During 20-22 October 2008, the NOAA 140 ship Nancy Foster used multibeam sonar to map areas likely to contain DSC and hard bottom 141 habitats. Guided by these maps, the R/V Seward Johnson and the Johnson Sea-Link II submersible 142 (JSL, Harbor Branch Oceanographic Inst., Florida Atlantic Univ.) surveyed the WFS (16-17 143 September 2009). The first 2010 cruise (28 September-2 October) addressed multidisciplinary 144 research objectives using the R/V Cape Hatteras and the remotely operated vehicle (ROV) Kraken II (Univ. Connecticut). The NOAA ship Ronald H. Brown and ROV Jason II (Woods Hole

146 Oceanographic Inst.) conducted one dive on the WFS (10 November 2010). Multibeam sonar 147 mapping was conducted by the Lost Coast Explorer (7-10 November 2010). During 20-22 March 148 2012, the NOAA ship Okeanos Explorer conducted multibeam mapping and two dives with the 149 ROV Little Hercules in the WFS study area. The area mapped during the 2008 cruise (Fig. 1, Area 150 A) is emphasized because more extensive data were collected there.

\subsection{Multibeam sonar surveys}

153 Part of the WFS (Fig. 1), centered on a previously described (Newton et al., 1987; Reed et al., 154 2006) hardground area, was surveyed during the 2008 Nancy Foster cruise using a Kongsberg155 Simrad EM1002 (95 kHz frequency, 111 beams per ping) multibeam sonar. An additional single 156 track line of multibeam sonar, attempting to follow the long scarp described below, was collected 157 south of the 2008 survey by the Lost Coast Explorer, using a Kongsberg EM710 (70-100 kHz

158 frequency, 400 beams per ping) multibeam system. During the Okeanos Explorer cruise additional 159 multibeam sonar data were collected using a Kongsberg EM302 (30 kHz frequency, 432 beams per 160 ping) to fill in deeper areas not mapped in previous cruises. Raw data were corrected and postprocessed using CARIS HIPS and SIPS (v. 6.1) to produce georeferenced color-shaded bathymetric 
162 maps (in ArcGIS v. 9.31, ESRI) gridded to $8 \mathrm{~m}$ (2008 survey), $3 \mathrm{~m}$ (2010 survey), and 10 and $25 \mathrm{~m}$ 163 (2012 survey) resolutions.

164 Features of the prominent scarp were described as follows. The highest points along the top 165 edge of the scarp were traced on the GIS map. The base of the scarp was more difficult to discern 166 because it often exhibited slumping, multiple terraces, and boulder fields. To resolve the scarp base, 167 the slope of each map cell $(8 \times 8 \mathrm{~m}$ or $10 \times 10 \mathrm{~m})$ in the raster dataset was calculated using ArcGIS, 168 and we identified the base of the scarp as those cells where the slopes either obviously changed 169 direction (as in boulder fields) or became flat. The scarp base was then also traced on the GIS map, 170 and the scarp face was defined the area between the top and base lines. Vertical relief of the scarp 171 was measured only in the 2008 survey area approximately every $50 \mathrm{~m}$ by subtracting the depth at 172 the top of the scarp from that at the base. The width of the scarp was measured at the same places 173 using the two-dimensional distance between the top and the base. The angular slopes of the scarp 174 face were calculated at the $50 \mathrm{~m}$ intervals by taking the arctangent of scarp relief divided by its 175 width.

176 Objectively identifying the numerous topographic highs (mounds and ridges) west of the scarp 177 was more difficult because these features varied greatly in size and shape, were often not 178 continuous (unlike the scarp), and geological features are frequently described in relative terms, 179 lacking explicit criteria such as slope angles (International Hydrographic Organization, 2013). 180 Multibeam derived topography was confirmed with visual surveys during submersible and ROV 181 dives, which generally focused on and around the most prominent features. The areas surveyed 182 during these dives were used to develop slope criteria to define other similar topographic highs west 183 of the scarp. First, a slope was calculated for each map cell $(8 \times 8 \mathrm{~m}$ or 10x10 $\mathrm{m})$ in the raster dataset 184 using ArcGIS, and cells were color coded by slope (Fig. 2). The map was overlaid with the dive 185 track habitat maps for this area (Fig. 2 A), which were simplified to reef (green outline) versus non186 reef (red outline) (Fig. 2 B, C). Next, cells were sequentially removed in $1^{\circ}$ increments (starting 187 with $0^{\circ}$ ) until topographic features (reef or non-reef) observed during the dives were clearly defined 188 by remaining cells. Reef features surveyed during dives were best identified when the majority of 189 cells had slopes $\geq 14^{\circ}$ (Fig. 2 C); therefore, clusters of cells with $\geq 14^{\circ}$ slopes were defined as 190 mounds or ridges in the mapped area A (Figs. 1, 3). An example of a progression of cell removal 191 illustrates that including slope angles $<9^{\circ}$ obscured the boundaries of large topographic features 
192 (Fig. 2 A, B). To more inclusively capture areas of the mounds/ridges, all cells with a slope $\geq 9^{\circ}$

193 were included as part of a topographic feature if they lay adjacent to the cells with slopes $\geq 14^{\circ}$

194 (Fig. 2 D).

195

196

197

198

199

200

201

202

203

204

205

206

207

208

209

210

211
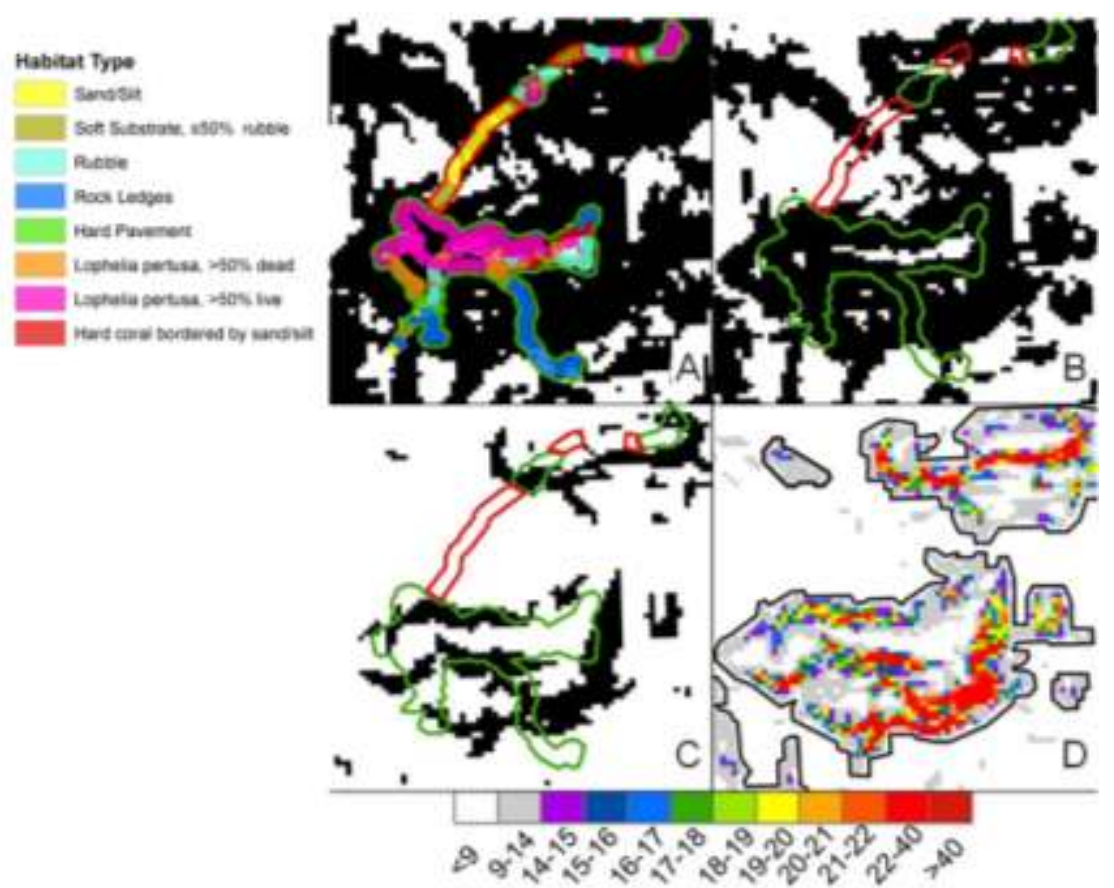

Figure 2

Slopes

Figure 2. Selected area of the southernmost dive sites on the WFS (see Fig. 3) illustrating sequential removal of slope cells. A portion of dive tracks is included in A with habitats color coded (see left sidebar). In $\mathrm{B}$ and $\mathrm{C}$ all reef habitats on the dive tracks are outlined in green, and non-reef habitats are outlined in red. $\mathrm{A}=$ black cells include all slopes $\geq 4^{\circ} . \mathrm{B}=$ black cells include slopes $\geq 6^{\circ} . \mathrm{C}=$ black cells include slopes $\geq 14^{\circ}$; note high slopes now correlated with reef areas (green outline) defined by dives. $\mathrm{D}=$ All slopes are color coded (bottom sidebar) and slopes $\geq 9^{\circ}$ are outlined in black. In panel D five features (outlined in black) are counted as elevated reef areas.

\subsection{Environmental data}

Environmental data were collected throughout the water column (to within ca. $10 \mathrm{~m}$ of bottom) using a SeaBird SBE 911plus at a data logging rate of 24 samples/sec. The six CTD casts made in 2008 (Fig. 3) recorded conductivity ( $\mu \mathrm{S} / \mathrm{cm})$, temperature $\left({ }^{\circ} \mathrm{C}\right)$, depth (m, calculated from pressure), altitude $(\mathrm{m})$, salinity (calculated), and dissolved oxygen (DO, $\mathrm{ml} / \mathrm{l})$ at various locations within the mapped area. Four CTD casts were made over a single coral mound (Fig. 3) in 2009, measuring the same parameters as in 2008, plus density $\left(\sigma_{\theta}, \mathrm{kg} \mathrm{m}^{-3}\right)$. Single CTD casts and cross-slope transects (stations spaced at ca. $500 \mathrm{~m}$ intervals) were completed during the $2010 \mathrm{R} / \mathrm{V}$ Cape Hatteras cruise 
212 (Fig. 3), measuring the same parameters as in 2009, plus pH and fluorescence (Chl- $\alpha, \mu \mathrm{g} / \mathrm{l})$. For

213 individual CTD casts, measured variables were plotted against depth. Profiles of selected variables

214 were plotted against depth and distance along the cross-slope transects using Surfer (v. 8) software.

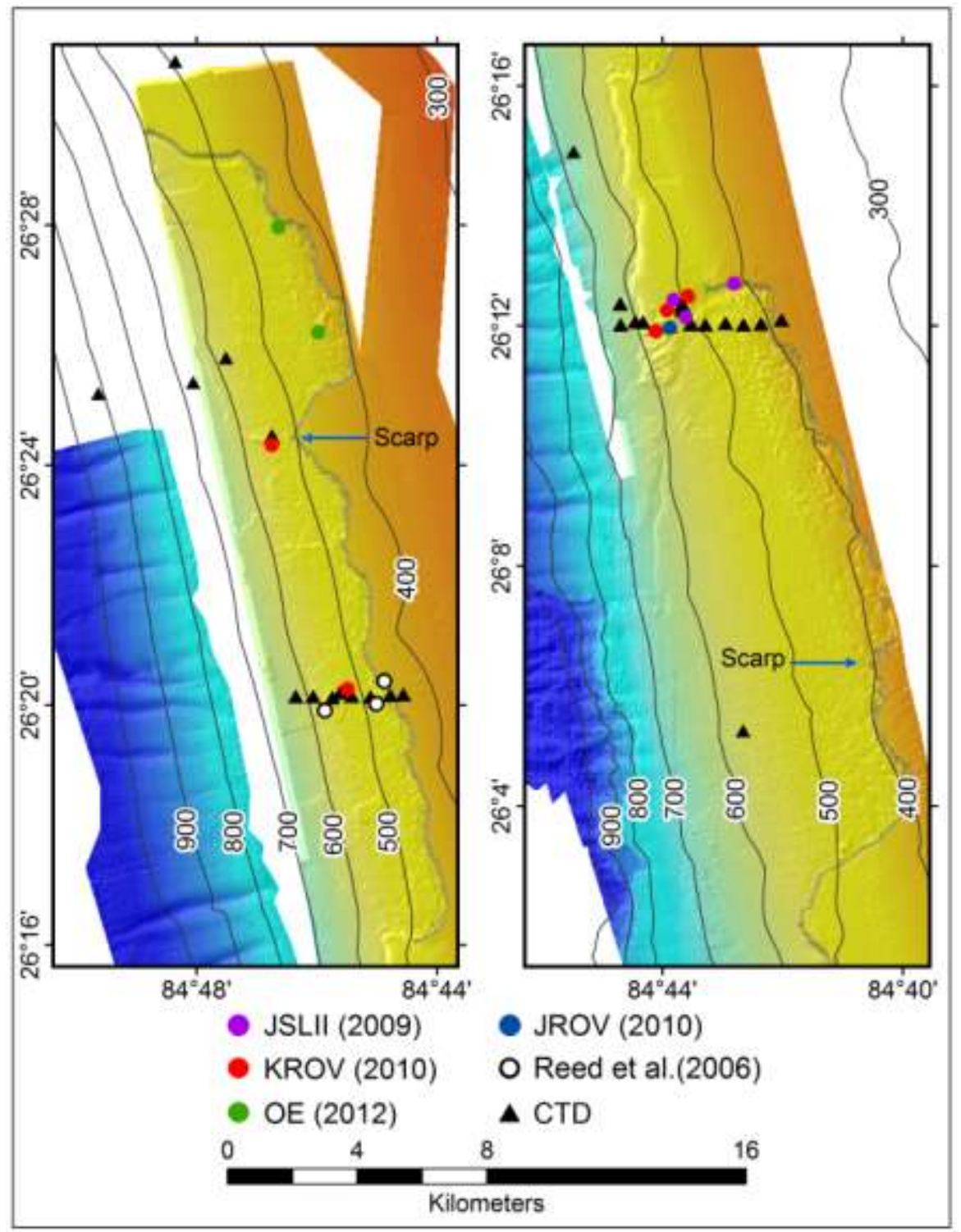

216 Figure 3. Larger scale view of the West Florida Slope surveyed with multibeam sonar during the 2172008 and 2012 cruises (A in Fig. 1), showing bathymetry, dive vehicle bottom starting points and 218 CTD stations. Note the bottom of the left panel joins the top of the right panel. See Figs. 7-9 for 219 habitat details along the dive tracks. The southernmost cluster of dives is the area also visited by 220 Hübscher et al. (2010).

Environmental data were also recorded during each underwater vehicle dive. The JSL used a

223 SeaBird SBE 19plus mounted about $2 \mathrm{~m}$ above its base to record conductivity $(\mu \mathrm{S} / \mathrm{cm})$, temperature 
$224\left({ }^{\circ} \mathrm{C}\right)$, depth (pressure), salinity (calculated), DO $(\mathrm{ml} / \mathrm{l})$, and $\mathrm{pH}$ once per second. The same 225 instrument package was also attached to the ROV Kraken II down-weight. While the ROV was on

226 bottom, the down weight was usually 15-20 m off bottom, but was sometimes closer to the bottom.

227 A Seabird SBE 37-SI mounted on the ROV Jason II recorded conductivity $(\mathrm{S} / \mathrm{m})$, temperature $\left({ }^{\circ} \mathrm{C}\right)$,

228 and depth (pressure) once per second. Only the data recorded while the vehicles were on or near

229 bottom are presented.

230

2.4 Bottom observations

232 High resolution video and still digital imagery were obtained during four cruises. Three dives

233 were completed on the WFS in 2009 using the JSL submersible, followed by five dives in 2010

234 using the ROV Kraken II, one dive in 2010 with the ROV Jason II, and two dives in 2012 using the

235 ROV Little Hercules (Table 1). Annotated video transects were conducted as described in Ross and 236 Quattrini (2007).

237 Dive videos were viewed multiple times for habitat classifications by time of observation and to 238 document distributions of DSC (to lowest possible taxa). Benthic habitat classifications were 239 modified from Partyka et al. (2007) and defined as follows: 1) Soft substrata (sand and/or silt), few 240 or no hard structures; 2) Soft substrata up to $50 \%$ covered in coral rubble (small, broken,

241 unconsolidated coral pieces, mostly L. pertusa) and/or small rocks, vertical height < $1 \mathrm{~m}$; 3) Rubble 242 bottom $>50 \%$ covered with coral rubble and/or small rocks, profile < $1 \mathrm{~m}$; 4) Rocky ledges and/or 243 boulders, profile > $1 \mathrm{~m}$; 5) Hard pavement, profile usually flat or < $1 \mathrm{~m}$; 6) Hard corals (L. pertusa 244 dominated), 80-100\% bottom cover, > 50\% dead, profile > $1 \mathrm{~m}$; 7) Hard corals (L. pertusa 245 dominated), 80-100\% bottom cover, $>50 \%$ live coral, profile $>1 \mathrm{~m}$, usually with high $\%$ of 246 attached sponges and other sessile fauna; 8) Isolated coral bushes surrounded by soft substrata and 247 often a high \% of surrounding coral or rock rubble. Any of the hard substrata, especially non-living 248 components, exhibited varying amounts of attached fauna. 
249 Table 1. Stations sampled on or near deep reefs in the eastern GOM during five cruises (NOAA ship Nancy Foster [NF], R/V Seward

250 Johnson [SJ], R/V Cape Hatteras [CH], NOAA ship Ronald H. Brown [RB], NOAA ship Okeanos Explorer [OE]). D=Day (0700-1830

251 hr EDT), N=Night (1830-0700 hr EDT). CTD=Seabird SBE 911+, JSL=Johnson-Sea-Link II submersible, KROV=Kraken II,

252 JROV=Jason II, OE ROV=Little Hercules. Submersible and ROV total times, latitudes, longitudes, and depth ranges are only for the

253 period when the vehicles were on the bottom. For CTD casts, depth ranges include the maximum depth of the sample to the surface (S).

\begin{tabular}{|c|c|c|c|c|c|c|c|c|c|}
\hline Station \# & Gear & Date & Time & $\begin{array}{l}\text { Total } \\
\text { Time } \\
\text { (min) } \\
\end{array}$ & $\begin{array}{c}\text { Start } \\
\text { Latitude } \\
\left({ }^{\circ} \mathbf{N}\right)\end{array}$ & $\begin{array}{c}\text { Start } \\
\text { Longitude } \\
\left({ }^{\circ} \mathbf{W}\right)\end{array}$ & $\begin{array}{c}\text { End } \\
\text { Latitude } \\
\left({ }^{\circ} \mathbf{N}\right)\end{array}$ & $\begin{array}{c}\text { End } \\
\text { Longitude } \\
\left({ }^{\circ} \mathbf{W}\right)\end{array}$ & $\begin{array}{c}\text { Depth } \\
\text { Range } \\
\text { (m) }\end{array}$ \\
\hline NF-2008-084 & CTD & 20-Oct-08 & $\mathrm{N}$ & 18 & $26^{\circ} 25.19$ & $84^{\circ} 49.64$ & & & S-757 \\
\hline NF-2008-085 & CTD & 21-Oct-08 & $\mathrm{N}$ & 20 & $26^{\circ} 25.79$ & $84^{\circ} 47.51$ & & & S-562 \\
\hline NF-2008-086 & CTD & 21-Oct-08 & $\mathrm{D}$ & 21 & $26^{\circ} 25.38$ & $84^{\circ} 48.06$ & & & S-660 \\
\hline NF-2008-087 & CTD & 21-Oct-08 & $\mathrm{D}$ & 9 & $26^{\circ} 30.73$ & $84^{\circ} 48.36$ & & & S-449 \\
\hline NF-2008-088 & CTD & 21-Oct-08 & $\mathrm{N}$ & 13 & $26^{\circ} 14.90$ & $84^{\circ} 45.48$ & & & S-649 \\
\hline NF-2008-089 & CTD & 22-Oct-08 & $\mathrm{D}$ & 12 & $26^{\circ} 05.25$ & $84^{\circ} 42.66$ & & & S-553 \\
\hline JSLII-2009-GOM-3722 & JSL & 16-Sep-09 & $\mathrm{D}$ & 158 & $26^{\circ} 12.19$ & $84^{\circ} 43.64$ & $26^{\circ} 12.31$ & $84^{\circ} 43.62$ & $536-500$ \\
\hline JSLII-2009-GOM-3723 & JSL & 16-Sep-09 & $\mathrm{D}$ & 157 & $26^{\circ} 12.43$ & $84^{\circ} 42.73$ & $26^{\circ} 12.71$ & $84^{\circ} 42.83$ & $428-414$ \\
\hline JSLII-2009-GOM-3724 & JSL & 17-Sep-09 & $\mathrm{D}$ & 161 & $26^{\circ} 12.23$ & $84^{\circ} 43.75$ & $26^{\circ} 12.47$ & $84^{\circ} 43.54$ & $531-477$ \\
\hline SJ-2009-GOM-002 & CTD & 16-Sep-09 & $\mathrm{N}$ & 21 & $26^{\circ} 12.30$ & $84^{\circ} 43.66$ & $26^{\circ} 12.39$ & $84^{\circ} 43.40$ & S-439 \\
\hline SJ-2009-GOM-008 & CTD & 16-Sep-09 & $\mathrm{N}$ & 21 & $26^{\circ} 12.36$ & $84^{\circ} 43.68$ & $26^{\circ} 12.34$ & $84^{\circ} 43.61$ & $\mathrm{~S}-459$ \\
\hline SJ-2009-GOM-012 & CTD & 17-Sep-09 & $\mathrm{N}$ & 15 & $26^{\circ} 12.29$ & $84^{\circ} 43.65$ & $26^{\circ} 12.34$ & $84^{\circ} 43.58$ & S-437 \\
\hline SJ-2009-GOM-014 & CTD & 17-Sep-09 & $\mathrm{N}$ & 16 & $26^{\circ} 12.27$ & $84^{\circ} 43.67$ & $26^{\circ} 12.26$ & $84^{\circ} 43.68$ & S-438 \\
\hline KROV-2010-CH-007 & ROV & 28-Sep-10 & $\mathrm{D}$ & 572 & $26^{\circ} 12.51$ & $84^{\circ} 43.58$ & $26^{\circ} 12.44$ & $84^{\circ} 43.52$ & $485-522$ \\
\hline KROV-2010-CH-008 & ROV & 29-Sep-10 & $\mathrm{D}$ & 562 & $26^{\circ} 11.75$ & $84^{\circ} 44.38$ & $26^{\circ} 11.88$ & $84^{\circ} 43.91$ & $530-584$ \\
\hline KROV-2010-CH-009 & ROV & 30-Sep-10 & $\mathrm{D}$ & 497 & $26^{\circ} 12.26$ & $84^{\circ} 43.94$ & $26^{\circ} 12.26$ & $84^{\circ} 43.77$ & $519-549$ \\
\hline KROV-2010-CH-010 & ROV & $01-O c t-10$ & $\mathrm{D}$ & 555 & $26^{\circ} 20.15$ & $84^{\circ} 45.68$ & $26^{\circ} 20.08$ & $84^{\circ} 43.34$ & $497-531$ \\
\hline KROV-2010-CH-011 & ROV & 02-Oct-10 & $\mathrm{D}$ & 310 & $26^{\circ} 24.46$ & $84^{\circ} 46.71$ & $26^{\circ} 24.39$ & $84^{\circ} 46.62$ & $494-522$ \\
\hline CH-2010-054 & CTD & 28-Sep-10 & $\mathrm{D}$ & 12 & $26^{\circ} 12.35$ & $84^{\circ} 43.67$ & $26^{\circ} 12.56$ & $84^{\circ} 43.72$ & S-493 \\
\hline CH-2010-055 & CTD & 28-Sep-10 & $\mathrm{N}$ & 8 & $26^{\circ} 12.10$ & $84^{\circ} 42.02$ & $26^{\circ} 12.08$ & $84^{\circ} 42.02$ & S-368 \\
\hline CH-2010-056 & CTD & 28-Sep-10 & $\mathrm{N}$ & 9 & $26^{\circ} 12.03$ & $84^{\circ} 42.36$ & $26^{\circ} 12.02$ & $84^{\circ} 42.30$ & $\mathrm{~S}-404$ \\
\hline CH-2010-057 & CTD & 28-Sep-10 & $\mathrm{N}$ & 10 & $26^{\circ} 12.02$ & $84^{\circ} 42.65$ & $26^{\circ} 12.03$ & $84^{\circ} 42.56$ & S-430 \\
\hline
\end{tabular}




\begin{tabular}{|c|c|c|c|c|c|c|c|c|c|}
\hline Station \# & Gear & Date & Time & $\begin{array}{l}\text { Total } \\
\text { Time } \\
\text { (min) } \\
\end{array}$ & $\begin{array}{c}\text { Start } \\
\text { Latitude } \\
\left({ }^{\circ} \mathbf{N}\right) \\
\end{array}$ & $\begin{array}{c}\text { Start } \\
\text { Longitude } \\
\left({ }^{\circ} \mathbf{W}\right)\end{array}$ & $\begin{array}{c}\text { End } \\
\text { Latitude } \\
\left({ }^{\circ} \mathbf{N}\right)\end{array}$ & $\begin{array}{c}\text { End } \\
\text { Longitude } \\
\left({ }^{\circ} \mathrm{W}\right)\end{array}$ & $\begin{array}{c}\text { Depth } \\
\text { Range } \\
\text { (m) } \\
\end{array}$ \\
\hline CH-2010-059 & CTD & 28-Sep-10 & $\mathrm{N}$ & 12 & $26^{\circ} 12.02$ & $84^{\circ} 43.29$ & $26^{\circ} 12.06$ & $84^{\circ} 43.16$ & S-489 \\
\hline CH-2010-060 & CTD & 28-Sep-10 & $\mathrm{N}$ & 12 & $26^{\circ} 12.03$ & $84^{\circ} 43.53$ & $26^{\circ} 12.07$ & $84^{\circ} 43.52$ & S-519 \\
\hline CH-2010-059 & CTD & 28-Sep-10 & $\mathrm{N}$ & 12 & $26^{\circ} 12.02$ & $84^{\circ} 43.29$ & $26^{\circ} 12.06$ & $84^{\circ} 43.16$ & S-489 \\
\hline CH-2010-061 & CTD & 28-Sep-10 & $\mathrm{N}$ & 13 & $26^{\circ} 11.99$ & $84^{\circ} 43.88$ & $26^{\circ} 12.09$ & $84^{\circ} 43.76$ & S-527 \\
\hline CH-2010-062 & CTD & 29-Sep-10 & $\mathrm{N}$ & 14 & $26^{\circ} 12.06$ & $84^{\circ} 44.33$ & $26^{\circ} 12.14$ & $84^{\circ} 44.43$ & S-600 \\
\hline CH-2010-063* & CTD & 29-Sep-10 & $\mathrm{N}$ & 11 & $26^{\circ} 12.07$ & $84^{\circ} 44.46$ & $26^{\circ} 12.06$ & $84^{\circ} 44.51$ & S-602 \\
\hline CH-2010-064 & CTD & 29-Sep-10 & $\mathrm{N}$ & 12 & $26^{\circ} 12.02$ & $84^{\circ} 44.70$ & $26^{\circ} 12.11$ & $84^{\circ} 44.74$ & S-632 \\
\hline CH-2010-074 & CTD & 29-Sep-10 & $\mathrm{N}$ & 18 & $26^{\circ} 12.37$ & $84^{\circ} 44.71$ & $26^{\circ} 12.63$ & $84^{\circ} 44.03$ & S-647 \\
\hline CH-2010-085 & CTD & $01-$ Oct-10 & $\mathrm{N}$ & 10 & $26^{\circ} 20.20$ & $84^{\circ} 45.62$ & $26^{\circ} 20.21$ & $84^{\circ} 45.56$ & S-509 \\
\hline CH-2010-086 & CTD & 01-Oct-10 & $\mathrm{N}$ & 8 & $26^{\circ} 20.17$ & $84^{\circ} 44.56$ & $26^{\circ} 20.19$ & $84^{\circ} 44.52$ & S-389 \\
\hline CH-2010-087 & CTD & $01-$ Oct-10 & $\mathrm{N}$ & 9 & $26^{\circ} 20.16$ & $84^{\circ} 44.77$ & $26^{\circ} 20.17$ & $84^{\circ} 44.80$ & S-453 \\
\hline CH-2010-088 & CTD & 01-Oct-10 & $\mathrm{N}$ & 10 & $26^{\circ} 20.14$ & $84^{\circ} 45.10$ & $26^{\circ} 20.15$ & $84^{\circ} 45.10$ & S-465 \\
\hline CH-2010-089 & CTD & 01-Oct-10 & $\mathrm{N}$ & 11 & $26^{\circ} 20.15$ & $84^{\circ} 45.41$ & $26^{\circ} 20.16$ & $84^{\circ} 45.39$ & S-478 \\
\hline CH-2010-090 & CTD & 01-Oct-10 & $\mathrm{N}$ & 12 & $26^{\circ} 20.12$ & $84^{\circ} 45.74$ & $26^{\circ} 20.15$ & $84^{\circ} 45.70$ & S-507 \\
\hline CH-2010-091 & CTD & 01-Oct-10 & $\mathrm{N}$ & 15 & $26^{\circ} 20.14$ & $84^{\circ} 46.06$ & $26^{\circ} 20.17$ & $84^{\circ} 45.99$ & $\mathrm{~S}-550$ \\
\hline CH-2010-092 & CTD & 01-Oct-10 & $\mathrm{N}$ & 14 & $26^{\circ} 20.14$ & $84^{\circ} 46.35$ & $26^{\circ} 20.16$ & $84^{\circ} 46.29$ & S-588 \\
\hline CH-2010-098 & CTD & 02-Oct-10 & $\mathrm{N}$ & 10 & $26^{\circ} 24.49$ & $84^{\circ} 46.74$ & $26^{\circ} 24.51$ & $84^{\circ} 46.69$ & S-498 \\
\hline JROV-2010-RB-542 & ROV & $10-$ Nov-10 & $\mathrm{N}$ & 320 & $26^{\circ} 11.92$ & $84^{\circ} 44.05$ & $26^{\circ} 12.29$ & $84^{\circ} 43.71$ & $492-555$ \\
\hline OE-ROV-01 & ROV & 20-Mar-12 & $\mathrm{D}$ & 367 & $26^{\circ} 28.00$ & $84^{\circ} 46.71$ & $26^{\circ} 28.77$ & $84^{\circ} 46.37$ & $395-452$ \\
\hline OE-ROV-02 & ROV & 22-Mar-12 & $\mathrm{D}$ & 403 & $26^{\circ} 26.21$ & $84^{\circ} 45.81$ & $26^{\circ} 26.29$ & $84^{\circ} 45.89$ & $396-429$ \\
\hline
\end{tabular}

*Data logger malfunctioned; data not used. 
Submersible and ROV dive tracks were initially processed to conservatively remove erroneous tracking data (location points) as described by Quattrini et al. (2012). Location points along the track were assigned habitat codes (1-8, see above) by matching the video time of the habitat code with the track point time code. Habitats could not be assigned for some video segments (poor image quality, too far off bottom), creating a few gaps (about $10 \%$ of the total track lengths) in the otherwise continuous bottom tracks. All location points were then plotted in ArcGIS. Dive tracks were further smoothed by conducting a three point moving average of the track points using ADELIE GIS module (v. 1.8, IFREMER). Dive track lines were created using the point to line function in ADELIE with a buffer of $10 \mathrm{~m}$ on each side of the track line. The resulting $20 \mathrm{~m}$ wide dive track was used as a mask for Inverse Distance Weighted (IDW) analysis using ArcGIS. To extend habitat values along the dive track between dive track points, IDW analysis was performed (power $=2$ and variable radius $=1$ ) on the smoothed dive track points. Habitat coded polygons were created from the IDW rasters, and these polygons were simplified (ArcGIS), which smoothed polygon edges. To obtain relative percent habitat contributions, areas $\left(\mathrm{m}^{2}\right)$ of each habitat type were determined using the ArcGIS Geometry Calculator.

\section{Results}

\subsection{Water mass characteristics}

Thirty-one water column CTD casts were made during three cruises (Table 1). Although the six casts made during the October 2008 cruise covered a large area (Fig. 3) spread over three days, data were comparable among casts, and all casts were plotted together (Fig. 4, upper panels). A sharp thermocline was observed between 50-60 m, with temperature declining rapidly from about $27^{\circ} \mathrm{C}$ to $15-16^{\circ} \mathrm{C}$ at a depth of about $200 \mathrm{~m}$ and thereafter declining less rapidly to about $6^{\circ} \mathrm{C}$ at $757 \mathrm{~m}$. Salinity exhibited a maximum $(\sim 36.5)$ between $60-100 \mathrm{~m}$ and steadily declined toward 35

284 thermocline, reaching an oxygen minimum $(2.7-2.8 \mathrm{ml} / \mathrm{l})$ around $200 \mathrm{~m}$. The oxygen minimum

285 layer persisted to about $600 \mathrm{~m}$, with oxygen values rising (to $2.8-3.5 \mathrm{ml} / \mathrm{l}$ ) with increasing depth 286 thereafter. 


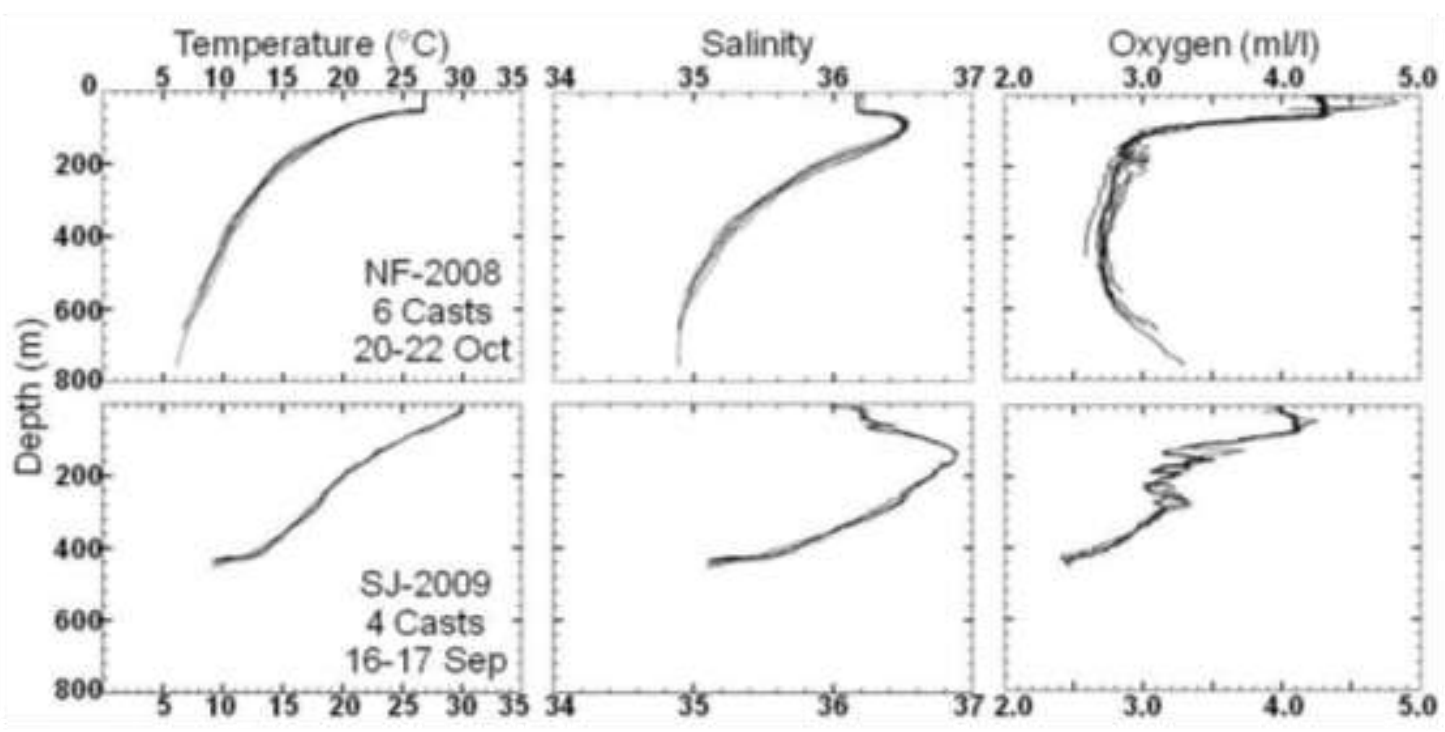

288 Figure 4. Temperature, salinity, and dissolved oxygen plots versus depth. The upper panel six

289 CTD casts conducted during the Nancy Foster cruise (20-22 October 2008) occurred throughout the 290 area of multibeam sampling, and the lower panel data of the four casts from the Seward Johnson cruise (16-17 September 2009) were all collected over the same coral mound (see Fig. 3 and Table

2921 for locations).

The four CTD casts made during 16-17 September 2009 over the same coral covered mound

295 (Fig. 3, Table 1) exhibited little variation, so these data were plotted together (Fig. 4, lower panels).

296 Unlike the other CTD casts, these profiles exhibited warmer $\left(30^{\circ} \mathrm{C}\right)$ surface temperatures, and 297 temperatures started to decline at a relatively shallow depth with no clear thermocline, until about $298400 \mathrm{~m}$ where temperature dropped rapidly toward $10^{\circ} \mathrm{C}$ with increasing depth. Temperatures were 299 warmer at all depths compared with data from the other cruises. Salinity overall and the salinity 300 maximum (ca. 36.8) were also higher for these four casts compared with the other salinity data. DO 301 values declined with depth (except for higher levels in the 40-60 m depth band), but also exhibited 302 variability with depth and no clear oxygen minimum layer. DO reached lower values $(2.4 \mathrm{ml} / 1$ at $303459 \mathrm{~m}$ ) at this site than those observed at most other sites or times (Figs. 4, 5). 


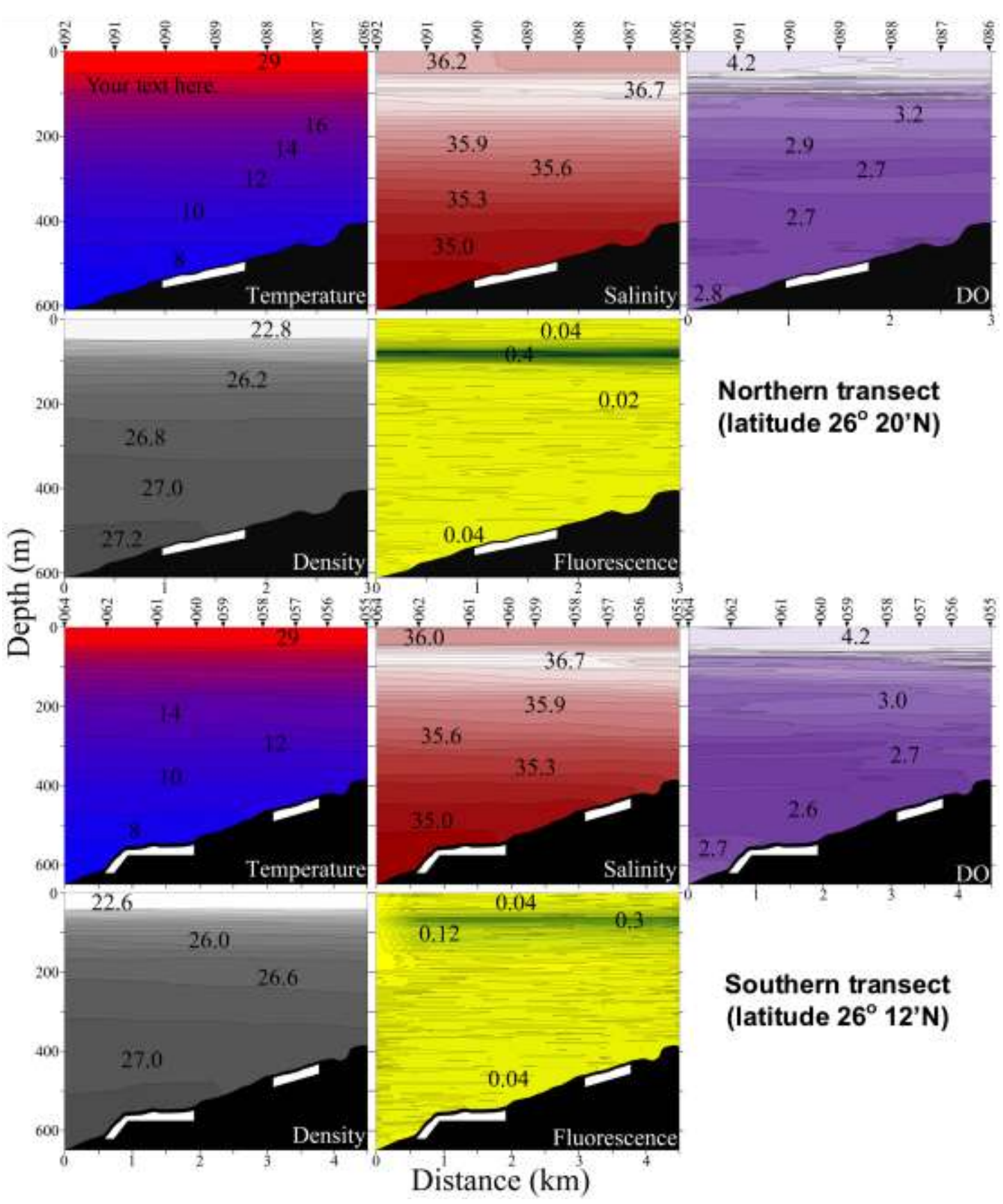

Figure 5. Cross-slope transects of temperature $\left({ }^{\circ} \mathrm{C}\right)$, salinity, dissolved oxygen (DO, ml/l), density $306\left(\sigma_{\theta}, \mathrm{kg} \mathrm{m}^{-3}\right)$ and fluorescence $(\mathrm{Chl}-\alpha, \mu \mathrm{g} / \mathrm{l})$. The northern transect (upper panels) was conducted on 1 307 October 2010 and the southern transect (lower panels) on 28-29 September 2010 (see Table 1 for 308 station details). The distance scale originates at the offshore stations with stations at approximately $309500 \mathrm{~m}$ intervals (See Fig. 3). The white bars represent the approximate locations of coral covered 310 mounds near the transects. Bathymetry was derived from the 2008 multibeam sonar survey.

312 The two cross-slope CTD transects conducted during the 2010 Cape Hatteras cruise (Fig. 5)

313 exhibited similar water mass patterns. There was little variability in parameter values across the 
314 transect stations at the same depths; most differences occurred with changing depth. Obvious

315 changes in most parameters occurred between about 50 and $100 \mathrm{~m}$ depths. As in the water column

316 casts described above, both transects revealed a high salinity (36.7) signature near $100 \mathrm{~m}$ that

317 persisted across the transects, and with increasing depth salinity declined slowly toward 35 at the

318 deepest stations. DO patterns were similar in both transects, except that high oxygen values (ca. 4

$319 \mathrm{ml} / \mathrm{l}$ ) persisted from the surface to a greater depth in the northern transect compared to the southern

320 transect. A DO minimum (ca. $2.6 \mathrm{ml} / \mathrm{l}$ ) layer, nearly $200 \mathrm{~m}$ thick, occurred in the depth zone

321 occupied by DSC. Cross-slope near bottom temperatures were 9.7 and $11.0^{\circ} \mathrm{C}$ at 390 and $369 \mathrm{~m}$

322 (stations 086 and 055, respectively) and dropped to 7.0 and $6.9^{\circ} \mathrm{C}$ at 589 and $634 \mathrm{~m}$ (stations 092

323 and 064, respectively) (Fig. 5). Near-bottom temperatures in the vicinity of coral habitats on the

324 north transect were $7.6-8.3^{\circ} \mathrm{C}(535-500 \mathrm{~m})$. For the southern cross slope transect, near-bottom

325 temperatures above the shallower coral habitat were $9.5-9.9^{\circ} \mathrm{C}$ at $410-425 \mathrm{~m}$, and above the deeper

326 coral habitat near bottom temperatures were $7.0-8.8^{\circ} \mathrm{C}$ at $505-620 \mathrm{~m}$. Chlorophyll- $\alpha$ activity

327 estimated by fluorescence exhibited typical patterns (higher concentrations near-surface, declining

328 with depth) in both cross-slope transects (Fig. 5). But, in the northern transect (1 October 2010) a

329 narrow more intense band of fluorescence was centered around $100 \mathrm{~m}$ compared with a more

330 diffuse, thicker band in the upper $100 \mathrm{~m}$ of the southern transect (28-29 September). Other water

331 column data did not reflect those fluorescence patterns (Fig. 5).

332 Bottom-water characteristics relevant to benthic habitats were recorded during the submersible

333 and ROV dives. During the two JSL dives on the ridges west of the scarp (JSLII-2009-GOM-3722,

334 3724) bottom temperature, salinity and DO varied little during the time on bottom (Table 2) despite

335 the JSL covering depth ranges of 36 and $54 \mathrm{~m}$, respectively, and substantial horizontal distances

336 (100s of meters) (Table 1). Also, little variability was observed for these parameters during a JSL

337 dive (JSLII-2009-GOM-3723) on the rocky scarp, except when bottom temperature varied

338 erratically over a range of nearly $2^{\circ} \mathrm{C}$ in the last hour of the dive. Salinity exhibited minor

339 variations during this period, and no obvious water mass anomalies or abrupt changes in depth were

340 observed. The highest bottom water temperature $\left(10.2^{\circ} \mathrm{C}\right)$ was recorded during this scarp dive,

341 which was also the shallowest dive that recorded temperature data (Table 1). Near-bottom

342 environmental data recorded during Kraken dives exhibited some variability (Table 2) due to

343 vertical movement of the down weight (location of sensors) in the water column. Usually the 
344 variations in temperature, salinity and DO were small during the five Kraken dives and were similar

345 to those recorded during the other dives (Table 2). Dive KROV-2010-CH-008 and to a lesser extent

346 dive 010 exhibited the highest variability in near bottom water temperature, DO and salinity, but

347 these variations probably resulted from rough seas and strong currents that caused the down-weight

348 to move through a larger than usual part of the water column. When the weight was pulled upward,

349 temperatures increased and were accompanied by a decrease in DO. DO $<1.8 \mathrm{ml} / 1$ was recorded

350 for almost two hours during dive 008, and this very low DO water overlying the coral covered ridge

351 was the lowest recorded during the study. The Jason dive covered a vertical depth range of $63 \mathrm{~m}$ on

352 bottom (Table 1) and recorded similar bottom-water temperatures (mean $=8.5^{\circ} \mathrm{C}$ ) and nearly the

353 same salinity patterns compared with other dives (Table 2).

355 Table 2. Bottom or near-bottom environmental data recorded during Johnson-Sea-Link II (JSLII), 356 Kraken II (KROV), Jason II (JROV) dives on the West Florida slope deep-sea reefs. Data are 357 means \pm SE of the means with ranges in parentheses during the bottom time portion of the dives.

358 DO=dissolved oxygen. See Table 1 for dive dates, bottom time durations and depth ranges.

\begin{tabular}{llcc}
\hline \multicolumn{1}{c}{ Dive } & Temperature $\left({ }^{\circ} \mathbf{C}\right)$ & \multicolumn{1}{c}{ Salinity } & DO (ml/I) \\
\hline JSLII-2009-GOM-3722 & $8.1 \pm 0.0(8.0-8.2)$ & $35.0 \pm 0.0(34.9-35.0)$ & $2.7 \pm 0.0(2.6-2.8)$ \\
JSLII-2009-GOM-3723 & $8.4 \pm 0.2(8.3-10.2)$ & $35.0 \pm 0.0(34.8-35.4)$ & $2.7 \pm 0.0(2.6-2.8)$ \\
JSLII-2009-GOM-3724 & $7.9 \pm 0.0(7.9-8.0)$ & $35.0 \pm 0.0(34.9-35.0)$ & $2.7 \pm 0.0(2.7-2.8)$ \\
KROV-2010-CH-007 & $8.5 \pm 0.3(8.1-9.1)$ & $35.0 \pm 0.0(35.0-35.1)$ & $2.7 \pm 0.0(2.7-2.8)$ \\
KROV-2010-CH-008 & $8.2 \pm 0.3(7.7-9.8)$ & $34.3 \pm 0.4(33.2-35.0)$ & $2.2 \pm 0.4(1.4-2.8)$ \\
KROV-2010-CH-009 & $8.3 \pm 0.1(8.1-8.6)$ & $35.0 \pm 0.0(34.8-35.1)$ & $2.7 \pm 0.0(2.7-2.7)$ \\
KROV-2010-CH-010 & $8.1 \pm 0.4(7.8-8.5)$ & $35.0 \pm 0.0(34.8-35.0)$ & $2.6 \pm 0.1(2.5-2.8)$ \\
KROV-2010-CH-011 & $8.4 \pm 0.0(8.2-8.6)$ & $35.0 \pm 0.0(34.9-35.0)$ & $2.7 \pm 0.0(2.6-2.7)$ \\
JROV-2010-RB-542 & $8.5 \pm 0.2(8.0-8.6)$ & $35.0 \pm 0.0(34.9-35.1)$ & \\
\hline
\end{tabular}
WFS study sites (Fig. 6). A south-flowing surface current would be expected if the eastern arm of

363 the LC were present, but surface currents in the study area were often setting to the northwest 364 during the cruises. In October 2008 the WFS study area was between the LC and a cold-core 365 cyclonic eddy. A trailing remnant of the main LC was near the area in September 2009 and may 366 have influenced the different water profile patterns recorded during the 2009 cruise (Fig. 4, lower 367 panel). LC patterns in September and November 2010 were similar to each other with minimal 
368 penetration of the LC into the GOM. During those months a large cold-core eddy was north of the

369 LC and was either south of (September) or over (November) the main WFS study area. The

370 greatest penetration of the LC into the GOM was observed during the March 2012 cruise; however,

371 the LC remained well west of the study area (Fig. 6).
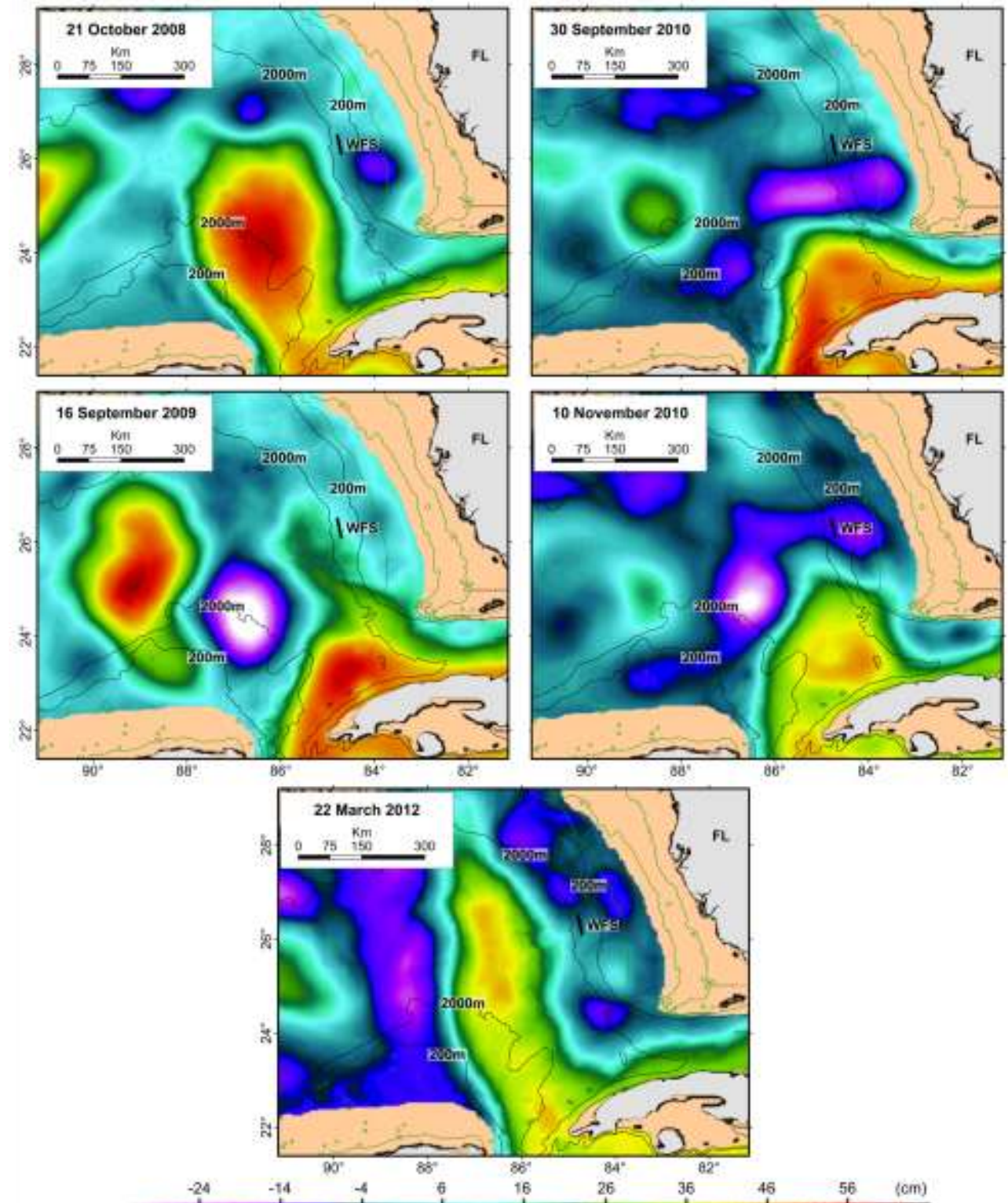

Figure 6

Sea Surface Height anomaly $(\mathrm{cm})$

Figure 6. Naval Research Lab Layered Ocean Model (high resolution) assimilating Sea Surface

374 Height (SSH) for five dates during this study's cruises. The anomaly SSH satellite maps show the

375 difference in measured sea height from the calculated mean sea level. A $+17 \mathrm{~cm} \mathrm{SSH}$ contour generally tracks the Loop Current and LC rings. Reds and yellows indicate higher SSH and warmer 
waters of the LC and LC eddies. Blue to purple colors are negative SSH anomalies, representing cold-core cyclonic eddies. The black rectangle is the main WFS study area (A in Fig. 1).

\subsection{Benthic terrain}

An area of the WFS extending over a distance of about $323 \mathrm{~km}$ and covering a total area of about $2479 \mathrm{~km}^{2}$ (Fig. 1) was mapped with multibeam sonar. The most prominent feature in the multibeam maps is a north-south trending scarp, the top of which usually occurs at depths of 375$500 \mathrm{~m}$ (average depth at top of scarp $=440 \mathrm{~m}$ ) and which is recognizable almost continuously for about $88 \mathrm{~km}$ (from $\sim 26^{\circ} 29.5^{\prime} \mathrm{N}$ to $\sim 25^{\circ} 52.3^{\prime} \mathrm{N}$ ). South of $25^{\circ} 52.3^{\prime} \mathrm{N}$ the scarp was not always obvious from the multibeam data but could still be traced for an additional $141 \mathrm{~km}$, yielding a total length of about $229 \mathrm{~km}$. The area of the scarp face in the region of the 2008 survey (Fig. 3) encompassed about $9.8 \mathrm{~km}^{2}$, and its width (horizontal distance between top and base) ranged from 103 to $680 \mathrm{~m}$ (mean=241 m). This portion of the scarp exhibited vertical heights of about 7 to 85 $\mathrm{m}$, with an average height of $47.5 \mathrm{~m}( \pm 13.3 \mathrm{SD})$. Angular slopes across the scarp face ranged from 1.5 to $20.4^{\circ}$, with some small scale local slopes estimated from submersible or ROV observations to be as steep as $90^{\circ}$. This part of the scarp exhibited numerous indentations and some changes in direction as abrupt as $90^{\circ}$ (Fig. 3). Although not completely mapped, the southern continuation of this scarp had vertical heights that ranged from $20 \mathrm{~m}$ in the northern part increasing to as much as $200 \mathrm{~m}$ in the south (around $24^{\circ} 37^{\prime} \mathrm{N}$ ).

Numerous scattered mounds and ridges occur west of the scarp. In the area in Figure 3 and to a lesser extent south of this area to at least $25^{\circ} 15^{\prime} \mathrm{N}$, some mounds and ridges occur immediately adjacent to the rocky scarp and others range up to $4200 \mathrm{~m}$ west of the scarp. In the mapped area of Figure 3 between about 400 and $700 \mathrm{~m}$ depths, we counted 907 discrete mounds and ridges with slopes $\geq 14^{\circ}$, covering in total about $14 \mathrm{~km}^{2}$ (area includes parts with slopes $\geq 9^{\circ}$, see methods). Vertical relief of these features was 6 to $37 \mathrm{~m}$ (mean $=15.2 \mathrm{~m}, \mathrm{SD}=5.84, \mathrm{n}=91$ ) (Figs. 7-9). Most of these hardbottom features occurred in depths between 450-550 $\mathrm{m}$ and were relatively uncommon 
403 below $600 \mathrm{~m}$. Unlike the scarp (Fig. 7), large areas of dead and living DSC colonies (dominated by

404 L. pertusa) occurred on nearly every mound or ridge where visual observations were recorded (Figs.

405 8, 9). On the sites where we made bottom observations (Figs. 8, 9), the area of reef habitat west of

406 the scarp was estimated to be about $1,726,650 \mathrm{~m}^{2}\left(1.73 \mathrm{~km}^{2}\right)(\mathrm{S} 1$ Fig., right panel inside black

407 boxes). This area included DSC, rocky structures, and some non-reef (soft substrata) habitat.

408 Relatively small areas of non-reef sandy bottom were included because they were inseparable from

409 reef areas on the scale (10s of meters) of our mapping.

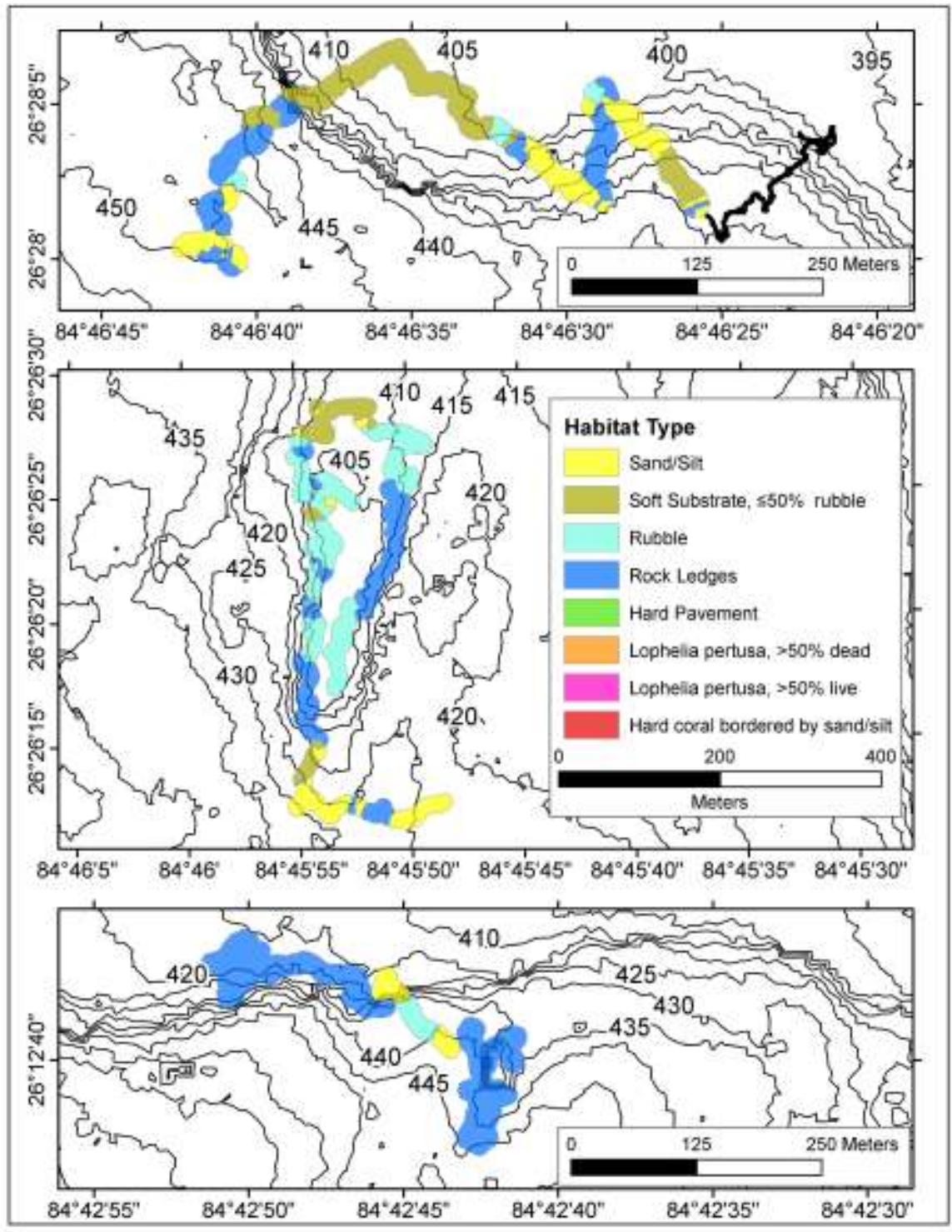


411 Figure 7. WFS dive track habitat maps along the rocky scarp, north to south. Upper panel is dive 412 OE-ROV-01, middle panel is OE-ROV-02, bottom panel is JSL3723 (see Table 1). The black track 413 line on the eastern end of the OE-ROV-01 dive shows the ROV track, but there were no video data. 414

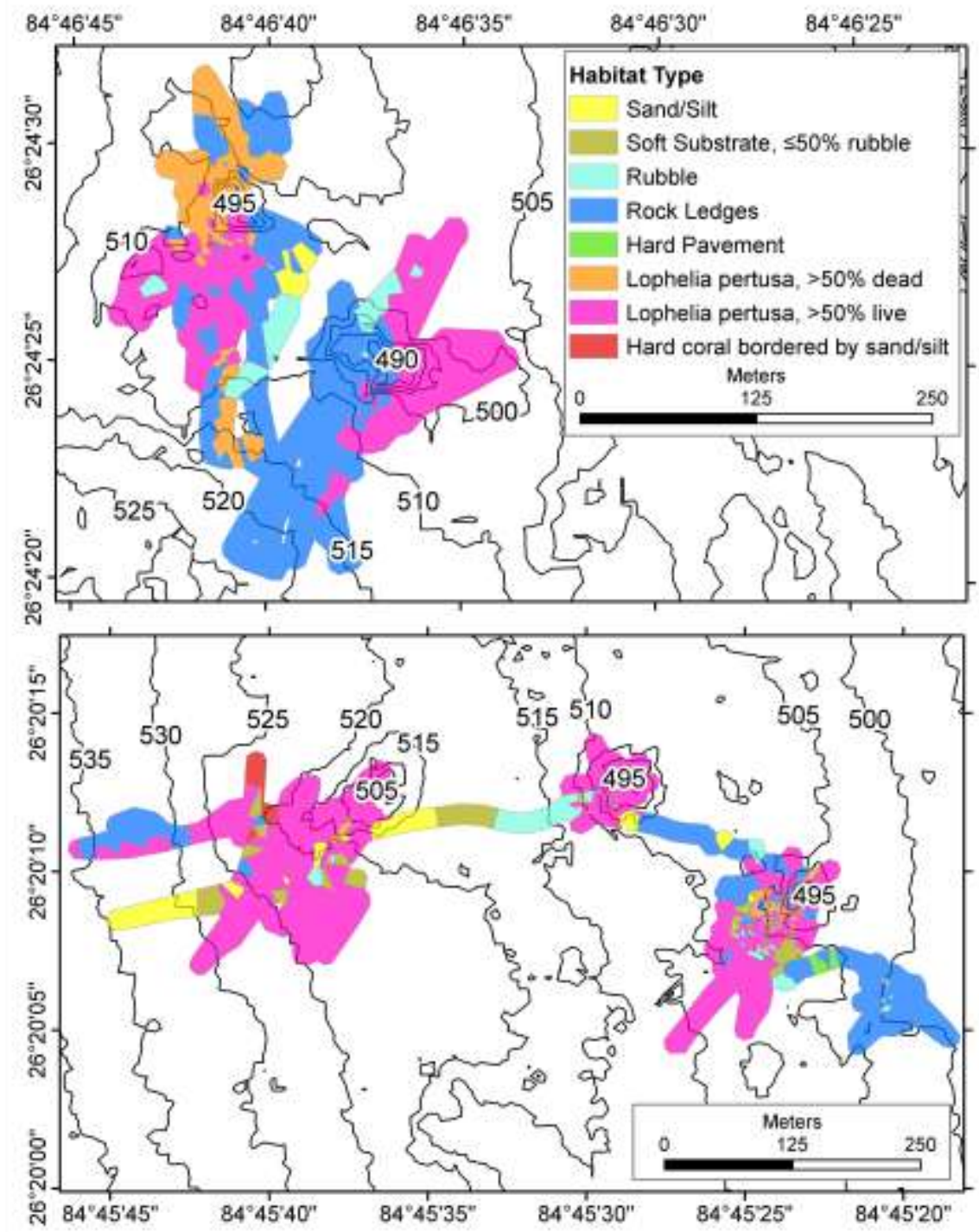

416 Figure 8. WFS dive track habitat maps of the mounds/ridges west of the rocky scarp. Upper panel 417 is dive KROV011, bottom panel is KROV010 (see Table 1). 


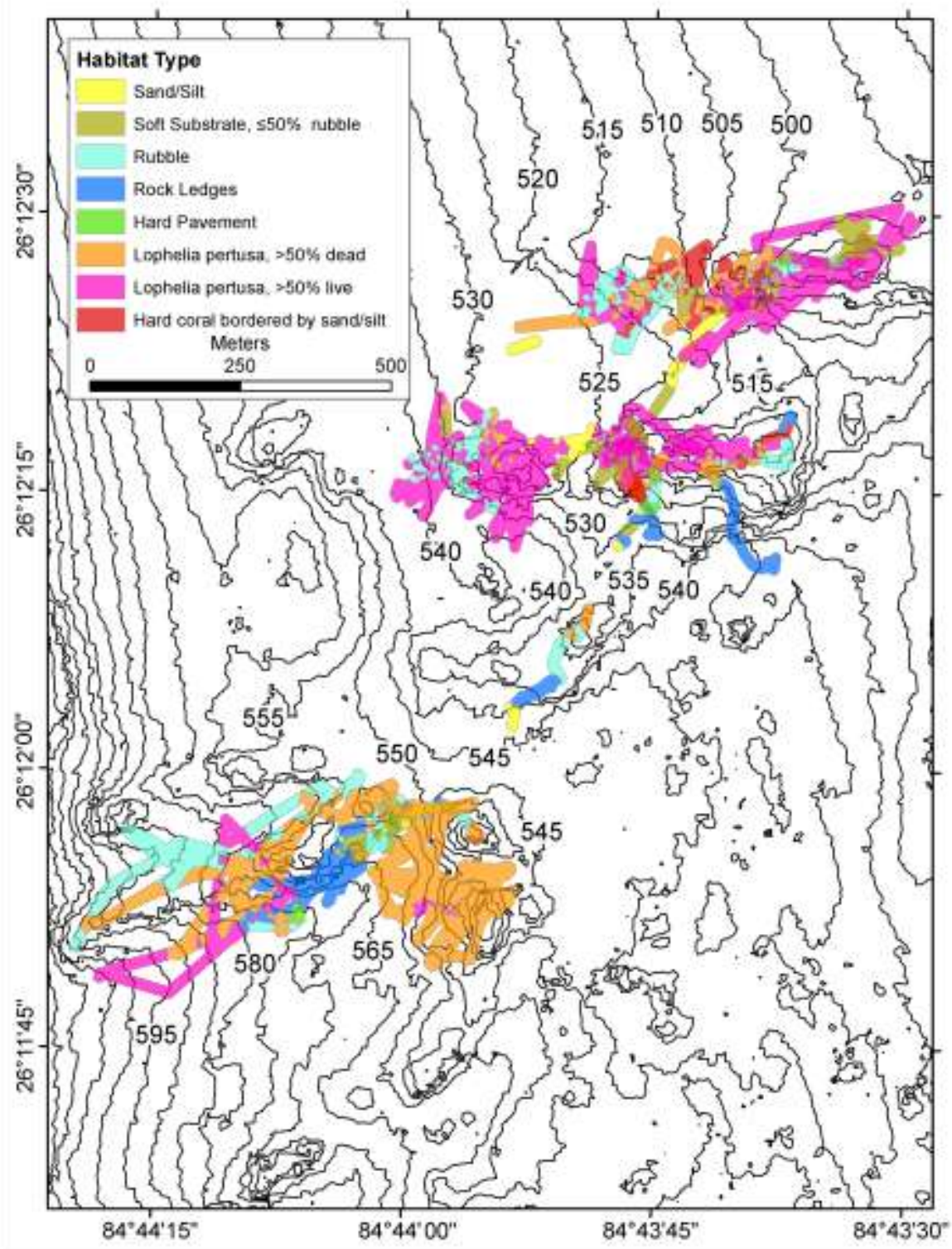

Figure 9

419 Figure 9. WFS dive track habitat maps of the mounds/ridges west of the rocky scarp. The southern 420 tracks are from dives JROV542 and KROV008; middle tracks are from JSL3722 and 3724 and 421 KROV009; northern tracks are from JSL3724 and KROV007 (see Table 1).

\subsection{Benthic habitat characterization}

424 Three submersible dives and eight ROV dives on the WFS resulted in $67.7 \mathrm{hrs}$ of bottom

425 observations over a total combined vehicle track distance of 56,746 m (56.75 km) (Table 1). The

426 north-south trending scarp (observations from dives JSLII-2009-GOM-3723, OE-ROV-01, OE-

427 ROV-02) was composed entirely of large rocky ledges and boulders with varying densities of 
428 attached, sessile invertebrates, including scattered small colonies of L. pertusa (Fig. 10 A), and

429 associated mobile fauna (Figs. 7, 10 A, B). In the vicinity of the JSL dive, the scarp exhibited a $90^{\circ}$

430 turn to run east-west before turning back north-south (Figs. 3, 7). These scarp ledges were less

431 heavily populated with fauna than the features to the west.

432 The mounds and ridges west of the scarp comprised a mix of various sized rocks and L. pertusa

433 bioherm structures, usually with coarse, sandy sediments between topographic highs (Figs. 8, 9). In

434 places the rocky ledges and boulders were similar in appearance to the scarp, with rocks varying in

435 color from white to shades of grey to black (Fig. 10 C). Large rocks were most commonly observed

436 at the bases and along the lower slopes of most of the ridges. Coral cover (both dead and living $L$.

437 pertusa colonies, Fig. 10 D, E) increased toward the crests of ridges and mounds, where the

438 substratum was a mixture of fine sediments trapped in coral rubble. These structures appeared to be

439 L. pertusa bioherms on top of a basement layer of rocks. Living coral colonies were most abundant

440 on the highest parts of mounds; however, observed live coral density was not higher on any

441 particular side of the mounds. More dead coral occurred on mounds below a depth of about $525 \mathrm{~m}$

442 compared with shallower depths (Figs. 8, 9).
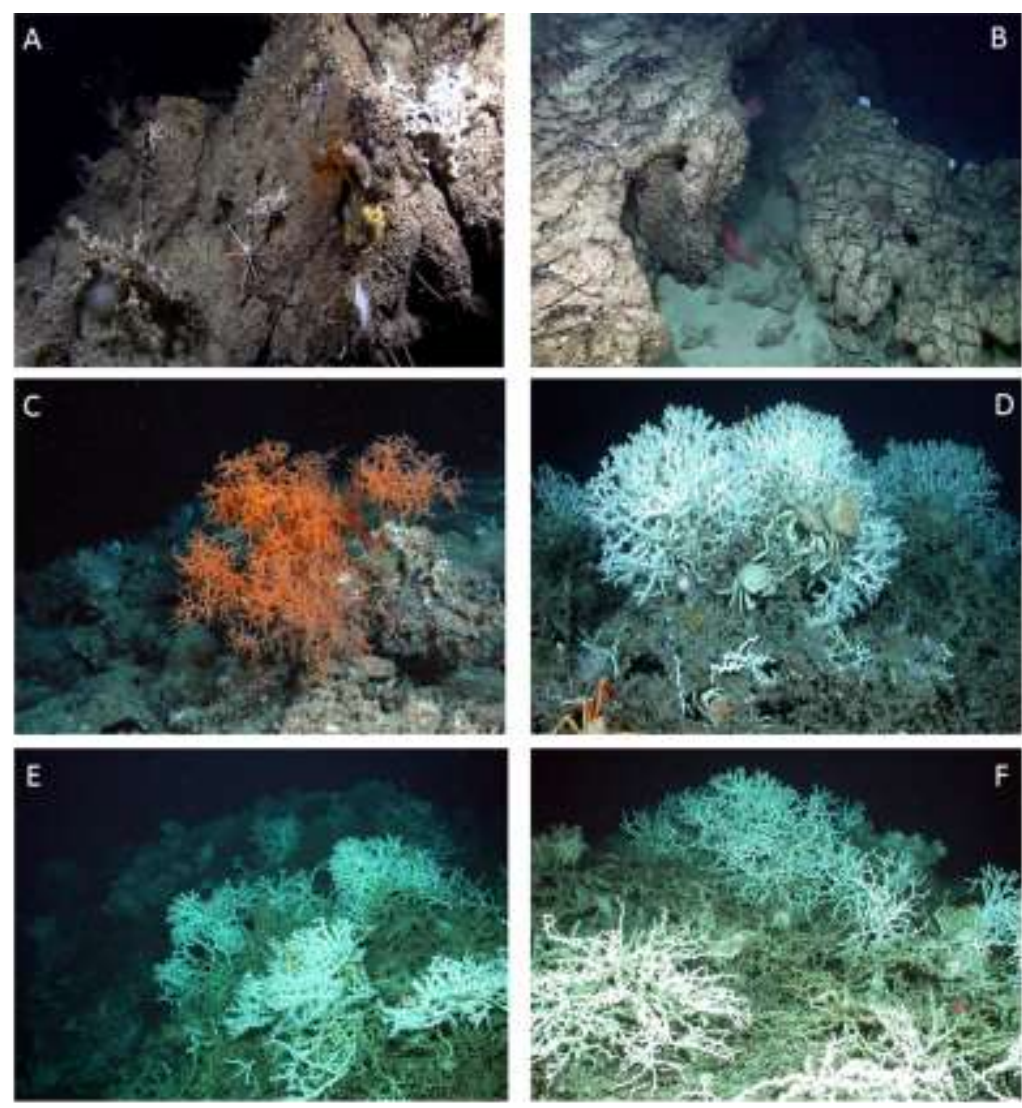
444 Figure 10. Images of WFS bottom habitats. A: WFS rocky scarp illustrating bare rock as well as associated fauna (e.g., Lophelia pertusa in upper right corner, red comatulid crinoid in right center, the echinoid Cidaris sp. in center, white hexactinellid sponge in left foreground), B: View of the rocky scarp illustrating more barren area, C: Rocky ridge west of the scarp with attached large red antipatharian (Leiopathes sp.), D: Golden crabs, Chaceon fenneri (center), closely associated with living and dead L. pertusa on top of a mound, D-F: Dense living L. pertusa on the top of mounds west of the scarp.

Habitats observed along the dive tracks were dominated by various types of hard-bottom complex structure (habitat types 3-8) (Table 3). Since visual surveys targeted elevated features,

454 these observations under-represent non-reef benthic habitats on the WFS. The most common 455 structure-forming habitat type was high profile, mostly living L. pertusa (32.42\% of area surveyed), 456 followed by high profile, mostly dead L. pertusa (19.20\%), rocky ledges or boulders (17.48\%) and 457 rubble (14.28\%). Low profile, hard pavement (0.35\%) was the least common hard substratum 458 (Table 3). In addition to L. pertusa, other colonial scleractinians included Madrepora oculata, 459 which commonly occurred in close association with L. pertusa (but not observed on the scarp) and 460 Enallopsammia profunda, which was relatively rare (especially as living colonies). The cup coral 461 Thecopsammia socialis often densely colonized dead L. pertusa and was also attached to exposed 462 rocks on the scarp and elsewhere. Antipatharian corals (particularly red and white morphotypes of 463 Leiopathes sp.) were usually restricted to the rocky structures (Fig. $10 \mathrm{C}$ ) rather than L. pertusa 464 dominated areas. Nephtheid octocorals (soft corals) occurred most commonly on the L. pertusa 465 rubble zones but were also attached to rocks. Two other octocorals, Anthomastus sp. and 466 Plumarella dichotoma, were common in coral rubble zones and attached to intact living and dead $L$. 467 pertusa. The hydrocoral Stylaster erubescens and other stylasterid species were commonly attached 468 to both rocky structures and dead L. pertusa.

469 Lost commercial fishing gear and trash were observed on a few occasions, but they were not 470 pervasive. These included pieces of monofilament tangled in the corals and traps $(\sim 1 \mathrm{x} 1 \mathrm{~m})$ that 471 were snagged in the rocks or corals. Some traps had buoy lines, one of which supported small 472 colonies of L. pertusa. 
474 Table 3. Habitat types $\left(\mathrm{m}^{2}\right)$ calculated over the dive tracks of JSL and ROV dives on the West Florida slope. 1=sand/silt; $2=$ soft

475 substrate, $\leq 50 \%$ rubble; $3=$ rubble; $4=$ rock ledges; $5=$ hard pavement; $6=$ L. pertus,$>50 \%$ dead; $7=L$. pertusa, $>50 \%$ live; $8=$ hard coral

476 bordered by sand/silt. Dives 007-011are Kraken II ROV, 3722-3724 are JSLII, 542 is the Jason II ROV, and 01-02 are Little Hercules

477 ROV. See Table 1 for dive station details and see Methods for habitat definitions.

\begin{tabular}{|c|c|c|c|c|c|c|c|c|c|c|c|c|c|}
\hline \multirow[b]{2}{*}{ Habitat } & \multirow[b]{2}{*}{007} & \multirow[b]{2}{*}{008} & \multirow[b]{2}{*}{009} & \multirow[b]{2}{*}{010} & \multicolumn{3}{|c|}{ Dives } & \multirow[b]{2}{*}{3724} & \multirow[b]{2}{*}{542} & \multirow[b]{2}{*}{01} & \multirow[b]{2}{*}{02} & \multirow[b]{2}{*}{ Totals } & \multirow[b]{2}{*}{$\%$} \\
\hline & & & & & 011 & 3722 & 3723 & & & & & & \\
\hline 1 & 1233 & 328 & 2113 & 3899 & 646 & 0 & 1377 & 2990 & 2421 & 5630 & 4980 & 25,617 & 5.66 \\
\hline 2 & 6697 & 3215 & 5296 & 3561 & 0 & 414 & 0 & 2964 & 2296 & 7448 & 4141 & 36,032 & 7.96 \\
\hline 3 & 8065 & 19419 & 5759 & 2718 & 2145 & 2014 & 869 & 2395 & 6327 & 943 & 14006 & 64,660 & 14.28 \\
\hline 4 & 9 & 10244 & 0 & 12894 & 18546 & 4886 & 11407 & 1400 & 3314 & 6517 & 9938 & 79,155 & 17.48 \\
\hline 5 & 0 & 582 & 0 & 350 & 0 & 0 & 0 & 261 & 370 & 0 & 0 & 1,563 & 0.35 \\
\hline 6 & 11879 & 60437 & 1560 & 1182 & 5758 & 1681 & 0 & 1895 & 2574 & 0 & 0 & 86,966 & 19.20 \\
\hline 7 & 32070 & 15170 & 33386 & 33074 & 14817 & 11356 & 0 & 5098 & 1844 & 0 & 0 & 146,815 & 32.42 \\
\hline 8 & 8240 & 65 & 1413 & 937 & 0 & 1435 & 0 & 0 & 0 & 0 & 0 & 12,090 & 2.67 \\
\hline Totals & 68193 & 109460 & 49527 & 58615 & 41912 & 21786 & 13653 & 17003 & 19146 & 20538 & 33065 & 452,898 & \\
\hline
\end{tabular}




\section{Discussion}

\subsection{Oceanography}

Several water masses are evident in the WFS study area. As at the Viosca Knoll coral mounds (Davies et al., 2010; Ross et al., 2010; Mienis et al., 2012), the upper $200 \mathrm{~m}$ of the WFS water column contained the high salinity signature of Subtropical Underwater (SUW) (Paluszkiewicz et al., 1983; Jochens and DiMarco, 2008; this study). Maintenance of high salinities (> 36.5) in this layer reflects lack of mixing and/or proximity to the Loop Current or a LC eddy (Jochens and DiMarco, 2008). The upper portion of Antarctic Intermediate Water (AAIW), characterized by lower salinity (35) than the SUW (Jochens and DiMarco, 2008) was identified in our deeper (> 500 m) CTD data. Under certain conditions this cold, nutrient-rich water is upwelled into shallower depths, as observed by intrusion of clearer, colder AAIW water at VK826 (Mienis et al., 2012) and also observed along the eastern Campeche Bank (Hebbeln et al., 2014). The low oxygen layer present throughout the WFS in the 400-500 m depth range (approximate depth of most living DSCs) is indicative of the North Atlantic Central Water. DSC in the GOM appear to generally occupy areas of low (<3.0 ml/1) DO (Davies et al., 2010; Ross et al., 2010; Lunden et al., 2014), which could impair growth rates or increase mortality (Davies et al., 2010; Lunden et al., 2014). However, extensive, living colonies of L. pertusa often occur where low DO conditions are common (Campeche Bank, WFS, Viosca Knolls, North Carolina), and this coral appears to be highly tolerant of low DO concentrations (Dodds et al., 2007; Brooke et al., 2009; Hebbeln et al., 2013). Even so, Lunden et al. (2014) reported complete mortality of L. pertusa under prolonged exposure to DO around $1.57 \mathrm{ml} / \mathrm{l}$, but suggested that GOM populations of this coral may be more adapted to low DO conditions than elsewhere in the Atlantic.

$$
\text { Interactions of the Loop Current and associated rings with the WFS and adjacent shelf are }
$$
similar to Gulf Stream boundary current interactions along the Atlantic slope off the SE United States (Paluszkiewicz et al., 1983; Vukovich and Maul, 1985) with eddies, meanders, upwelling, and diverse current patterns influencing climate, oceanography and biology. As observed during this study, the LC presently may have only limited direct contact with the DSC depth zone on the WFS, but it may have been more active in eroding the WFS during past lower sea levels (Doyle and Holmes, 1985). The LC meanders laterally and its variable degree of penetration into the GOM is 
509 controlled by its position and flow through the Yucatan Channel (Molinari and Morrison, 1988;

510 Candela et al., 2002). On average, the LC reaches maximum northward intrusions in winter (in 511 contrast to Hübscher et al., 2010) or early summer (Behringer et al., 1977; Molinari, 1980; Maul

512 and Vukovich, 1993). During our cruises, the LC was usually south of the main study area, as is

513 common in the fall, and the similarity of water column patterns over three years suggests longer

514 term consistency in these conditions (at least in the fall). Even when the LC strongly penetrates the

515 GOM, the south flowing eastern limb is often west of the WFS deep-reef sites. Deeper bottom

516 currents under the LC off the WFS often flow northward or northwestward (Hamilton, 1990), and

517 northward flows of deep water along the margins of the LC occur periodically (Molinari and Mayer,

518 1982; Vukovich and Maul, 1985). Hübscher et al. (2010) suggested that north-flowing bottom

519 currents caused much of the erosion along the WFS scarp, although this was not based on

520 oceanographic measurements. Lindberg and Lockhart (1993) also reported a north-flowing bottom

521 current in this area.

522 Current patterns likely play important roles in slope-depth faunal connectivity between the

523 GOM and the western North Atlantic. For example, L. pertusa spawns in the fall in the GOM

524 (Brooke, in press), and since the LC often exhibits limited penetration into the GOM in the fall or is

525 westward of the WFS, transport of L. pertusa larvae by the LC from the WFS into the Atlantic may

526 be restricted. Instead, the frequent north-flowing bottom currents noted above could send WFS

527 larvae further into the GOM. Such potential limits to dispersal during the spawning season may

528 explain the genetic separation between populations of L. pertusa from the north-central GOM and

529 those in other parts of the North Atlantic (Morrison et al., 2011). Similarly, lack of LC penetration

530 into the GOM and interference from LC rings prevented most of the oil from the Deep-Water

531 Horizon oil spill from entering the Atlantic or affecting the west and east Florida coasts (Liu et al.,

532 2011). Young et al. (2012) noted that planktonic larval duration was strongly correlated with

533 maximum dispersal distance and predicted that several deep-sea species exhibiting larval durations

$534 \geq 210$ days should be able to disperse considerable distances along the US east coast from the north-

535 central GOM. However, larvae with shorter lifespans would be retained closer to the region where

536 spawned. Laboratory studies suggest a larval duration of 20 to 56 days for L. pertusa (Larsson et

537 al., 2014), with the shorter duration more likely in situ. This relatively short larval duration suggest

538 regional, rather than basin-scale dispersal potential for L. pertusa. Thus, currents, reproductive 
539 timing, and larval duration may often limit GOM L. pertusa to relatively localized recruitment

540 within the GOM. Given current patterns and biology noted above, L. pertusa from the WFS are

541 likely more closely related to conspecifics in the northern GOM than elsewhere in the North

542 Atlantic (an hypothesis that requires testing), but deviations from the average oceanographic

543 conditions may facilitate periodic transport of larvae into the Atlantic, thereby maintaining some

544 level of gene flow as reported by Morrison et al. (2011). The wider occurring lineage of the black

545 coral, Leiopathes $c f$. glaberrima, exhibited a homogeneous population structure across the GOM

546 (including WFS and VK sites, Brooks et al., 2016), but Atlantic relationships remain unknown. In

547 contrast, WFS octocoral communities may differ genetically from those of the north-central GOM

548 because of a biogeographic boundary at mid-slope depths, perhaps caused by a LC barrier (Quattrini

549 et al., 2014), but the influences of reproductive timing, larval biology, and response to currents for

550 these octocorals are not known. To better understand the recruitment and distribution dynamics of

551 L. pertusa, genetic relationships between populations within the GOM and those upstream (e.g., on

552 the Campeche Bank) and downstream (off the SEUS) need to be clarified.

553 Most well-developed DSC stands along continental margins are associated with areas of high

554 nutrient input to surface waters from upwelling or freshwater flow, resulting in enhanced

555 productivity and particle delivery to the seafloor (Roberts et al., 2009). The increased surface

556 primary productivity resulting from the influx of nutrient-rich, Mississippi River derived waters

557 may ultimately support the dense coral communities at the Viosca Knolls (Mienis et al., 2012).

558 Primary productivity on the WFS is also enhanced by upwelling of colder, nutrient-rich waters as a

559 result of fluctuations in the LC (Paluszkiewicz et al., 1983; Vukovich and Maul, 1985; He and

560 Weisberg, 2003). Compared with the outer shelf, higher bottom organic carbon values were

561 reported on the upper slope near the deep reefs described here, and this could result from increased

562 primary productivity associated with the LC (Mullins et al., 1988a). Newly discovered DSC

563 communities off northeastern FL (Ross et al., 2015) as well as the extensive DSC province recently

564 described on the northeastern Campeche Bank (Hebbeln et al., 2014) also occur in areas of high

565 surface productivity driven in part by upwelling.

566

567

4.2 Geological Structure 
568 Deep reefs occur within at least two quite different geological provinces along the GOM 569 continental slope (Bouma and Roberts, 1990; Roberts, 2011). The north-central GOM is a

570 siliciclastic province with numerous salt diapirs, hydrocarbon seeps, and hard substrata produced by 571 authigenic carbonate precipitation. In contrast, the WFS, (De Soto Canyon to the Straits of Florida), 572 is a complex, relatively smooth, carbonate ramp transition zone between the continental shelf and 573 the GOM basin (Doyle and Holmes, 1985; Mullins et al., 1988a, b). The narrower southern 574 subsection of the WFS containing our study area exhibits steeper slopes and more frequent 575 hardbottom outcroppings than the northern subsection (Brooks and Holmes, 2011). The 400-600 m 576 depth zone is characterized by outcrops of phosphorites and carbonate hardgrounds surrounded by 577 coarse grained, winnowed sediments (Mullins et al., 1988a); however, outcrops are rare north of $26^{\circ}$ $57840^{\prime} \mathrm{N}$ (Doyle and Holmes, 1985). Sediments are composed of biogenic carbonates that grade from 579 coarse grained (foraminifera, pteropods, and larger carbonate-based fragments) to fine grained 580 (coccolithofore and foraminifera ooze) with increasing depth (Mullins et al., 1988a; Gardulski et al., 581 1990). The sediment overlay in this depth zone is often thin or lacking (minimal around $525 \mathrm{~m}$ ), 582 potentially a result of periodic interaction of the LC with the upper slope (Doyle and Holmes, 583 1985). Mass wasting also moves sediments westward from the WFS toward the deeper Florida 584 Escarpment (Brooks and Holmes, 2011). Many of the WFS coral mounds and surroundings are 585 superficially similar to those in the same depth range on the Campeche Bank (Hebbeln et al., 2014). 586 The combination of rocky ledges and scarps mixed with putative L. pertusa bioherms on the WFS 587 also resembles habitats in the same depth ranges in the Atlantic Ocean off Jacksonville, FL, where numerous ledges and bioherm-like structures were documented (Paull et al., 2000; Reed et al., 2006; Partyka et al., 2007; Ross et al., 2015). It is unclear whether underlying geological

591 GOM are similar: DSC colonization of various hard substrata and in some places, with appropriate 592 currents and sedimentary regimes, subsequent formation of elevated bioherms. In the GOM and 593 elsewhere, the exposure of various hard substrata and the build-up of coral bioherms appears to be 594 facilitated by strong currents (i.e., Loop Current, Gulf Stream) (Doyle and Holmes, 1985; Paull et 595 al., 2000).

596 The prominent long rocky scarp that defines the eastern portion of this study area is a Miocene597 aged outcropping of phosphorites formed and maintained by LC erosion (when the LC swings 
598 inshore or in prior geological eras) (Doyle and Holmes, 1985; Mullins et al., 1988a; Holmes, 1981).

599 Our description of the scarp agrees with previous reports (scarp profiles of 32-38 m) (Lindberg and

600 Lockhart, 1993; Reed et al., 2006; Hübscher et al., 2010). Hübscher et al. (2010) noted a moat

601 channel at the base of the scarp (same area as our southernmost dives), a feature also apparent in

602 most of our sonar data. The northern extent to which we mapped the scarp was $26^{\circ} 30^{\prime} \mathrm{N}$, but

603 Newton et al. (1987) illustrated it to about $27^{\circ} 10^{\prime}$ N. Although not completely mapped and

604 perhaps buried or partially buried in places, the scarp may be continuous at depths of 250-500 m

605 from off west-central Florida south to the Florida Keys where it may join a similar feature identified

606 in Lidz et al. (2006). In depths below 300 m, this extensive hardground scarp represents a

607 substantial potential substratum for DSC, other sessile invertebrates, and their associates.

608 Numerous mounds and ridges occurred west of the scarp in the 400-600 m depth zone. These

609 outcrops, likely once part of the scarp, were interpreted as Pleistocene aged hardgrounds composed

610 of calcarenites and phosphatic limestone likely resulting from past erosion by the LC (Newton et al.,

611 1987; Mullins et al., 1988a, b). Hübscher et al. (2010) suggested that one of the ridges that we

612 examined may have resulted from mass wasting (from the scarp) and that mounded sediments at the

613 base of the scarp may be contourite drifts formed by north flowing bottom currents. Over 900

614 mounds and ridges were counted within the northern part of the study area (parts of Fig. 3 mapped

615 with multibeam sonar between the 400-700 m contours), and many more likely occur to the south,

616 but this area was less well mapped. Because our methods for identifying mounds were conservative

$617\left(\geq 14^{\circ}\right.$ slopes, limits to sonar resolution), there are probably many smaller hardground or DSC

618 structures within this region.

619 These mounds and ridges provide abundant attachment sites for DSC, which are dominated by

620 L. pertusa. DSC mounds on the WFS were first reported to range over approximately $20 \mathrm{~km}$ along

621 the $500 \mathrm{~m}$ isobath and include mostly dead colonial scleractinians (Newton et al., 1987). From a

622 single video transect across a mound in the same area as Newton et al. (1987), Reed et al. (2006)

623 observed a terraced structure and up to $20 \%$ living L. pertusa coverage on the mound top, noting

624 that most live coral was on the northeast face. Hübscher et al.'s (2010) north-south camera transect

625 (overlapping some of our southern-most dives) documented a variety of bottom types, including

626 mounds formed by stacked boulders colonized by living and dead L. pertusa and other DSC.

627 Contrary to Reed et al. (2006), they reported DSCs concentrated on the southern flanks of the 
628 mounds, facing a predicted north-flowing bottom current. These limited transects across a few

629 mounds were not adequate to determine WFS coral distributions. Our multibeam sonar and visual

630 observations indicated DSC concentrations occurred over a much larger area than previously

631 reported, and the DSC covered all sides and tops of several major mound/ridge clusters. Patterns in

632 directionality of concentrations of living or dead L. pertusa could not be resolved, and most of the

633 living DSCs were consistently observed on and near the tops of features, with most living corals

634 usually shallower than about $525 \mathrm{~m}$.

635 We maintain that some mounds along the WFS are in various stages of bioherm formation (see

636 Roberts et al., 2009), with the existing rocky boulders forming the original coral attachment

637 substrata. Based on stacked hyperbolae seismic reflections and limited visual observations,

638 Hübscher et al. (2010) concluded that the WFS mounds were not coral-built, but that corals only

639 colonized existing hard substrata. Although true that corals colonize the hardgrounds, the role of $L$.

640 pertusa in WFS mound construction requires further consideration. In many DSC areas in the

641 GOM, off the SEUS, and in other regions, multiple stacked reflection hyperbolae [for examples see

642 Mienis et al., 2006; Ross and Nizinski, 2007) were characteristic of putative coral bioherms. In

643 most cases visual observation of those mounds did not reveal exposed rocky formations (although

644 some may have been buried within the mounds), but they appeared to be complexes of

645 unconsolidated sediments and coral rubble, capped with living and/or dead coral. The upper

646 portions of many of the structures on the WFS (west of the scarp) exhibited this same coral and

647 sediment matrix as observed elsewhere, the major difference being that boulders occurred in places,

648 especially along the bases of mounds. Although rocky components are more prominent on the WFS

649 compared with some DSC ecosystems outside the GOM, visual data suggested that at least parts of

650 these mounds are biogenic. If corals continue to grow and entrap sediment, the rocky components

651 may eventually be buried completely.

652 In summary, the portion of the WFS examined in this study is oceanographically dynamic and

653 geologically complex. The interplay of hard substrata outcrops with strong currents and upwelling

654 probably encouraged the development and maintenance of extensive DSC communities. Assuming

655 that all or most of the corals were dead, Newton et al. (1987) proposed that the WFS mounds

656 represented extinct or relict systems; however, their hypotheses were hampered by limited data,

657 especially on the abundant living DSC on the WFS. Our data suggest that the area of DSC 
658 (especially scleractinians) and deep-reef habitat is more extensive along the WFS than elsewhere in 659 the GOM, although Campeche Bank should be further explored. This is particularly striking, given 660 that DSC ecosystems in the northern GOM have been more extensively mapped and studied over 661 the last 12 years, while most of the WFS hardgrounds are unexplored. Thus, the extent of DSC on 662 the WFS is likely much larger than documented here. Considering that deep-coral habitat models 663 tend to overpredict habitat suitability (Davies and Guinotte, 2011; Georgian et al., 2014), such 664 models suggested much more DSC habitat at the VK sites (Georgian et al., 2014) than we noted (S1 665 Fig.), but the areas of highest coral concentrations coincided with our observations for VK sites. A 666 DSC area on Campeche Bank was recently reported to be at least $40 \mathrm{~km}^{2}$, larger than any such 667 biotope yet documented in the GOM, but the exact area included was unclear (Hebbeln et al., 2014). 668 Our intensively surveyed parts of the WFS exhibiting high DSC accumulations totaled $1.727 \mathrm{~km}^{2}$ 669 (black boxes, S1 Fig.), but if the area surveyed by multibeam sonar that includes the scarp and other 670 topographic highs is included, the DSC and deep reef province of the WFS is at least $157 \mathrm{~km}^{2}($ blue 671 boxes, S1 Fig.). Additional multibeam sonar mapping coupled with sub-bottom profiling, bottom 672 coring, oceanographic information and visual surveys are needed to better understand the complex 673 WFS and the processes influencing DSC accumulations. More extensive and varied explorations of 674 the WFS will benefit habitat and associated community management, especially considering 675 possible expansions of bottom fisheries and energy industry activities into deeper water.

676 Conservation strategies similar to those undertaken for DSC ecosystems off the SEUS (Martin, 677 2015) and along the US middle Atlantic (see https:// www.greateratlantic.fisheries.noaa.gov/stories/ 678 2016/september/26_deepsea_corals_in_the_mid-atlantic.html, 2016), are being considered by the 679 Gulf of Mexico Fishery Management Council to ensure the long term integrity of the DSC and 680 rocky deep reefs of the GOM. 


\section{Acknowledgments}

697 We thank Dr. G. Brewer (formerly USGS) for support and assistance during the project. We thank

698 all cruise science personnel for their hard work at sea and in dealing with logistics and data before

699 and after the cruises. The encouragement and support of G. Boland (BOEM) during these studies is

700 appreciated. We thank S. Cairns and D. Opresko for help with DSC identifications. D. Naar and E.

701 Cordes generously provided multibeam data collected at WFS (Lost Coast Explorer) and VK sites

702 (NOAA ship Nancy Foster). M. Partyka assisted with multibeam operations on the Nancy Foster.

703 We thank the ship and shore based personnel who operated the R/V Seward Johnson, R/V Cape

704 Hatteras, NOAA ship Nancy Foster, NOAA ship Ronald H. Brown, NOAA ship Okeanos Explorer,

705 and Lost Coast Explorer for their assistance during the cruises. Our thanks to W. Jaap for

706 constructive comments on this manuscript. Finally, we thank the personnel of the Johnson-Sea-

707 Link II, Kraken II, and Jason II for exemplary service during the missions.

\section{Author Contributions}

710 Conceived of the study, was Chief Scientist on 3 cruises and co-led one cruise: SWR. Directed and 711 conducted most analyses, including data management: MR, SWR. Participated in cruises: SWR,

712 MR, SDB. Co-Chief Scientist on one cruise, assisted with data collection, reviewed coral data:

713 SDB. Wrote the paper: SWR, MR. Reviewed and edited manuscript drafts: SDB, MR.

\section{References}

Behringer, D.W., Molinari, R.L., Festa, J.F., 1977. The variability of anticyclonic current patterns in the Gulf of Mexico. Journal of Geophysical Research 82, 5469-5476.

Bouma, A.H., Roberts, H.H., 1990. Northern Gulf of Mexico continental slope. Geo-Marine Letters 10, 177-181.

Brooke, S., Schroeder, W.W., 2007. State of deep coral ecosystems in the Gulf of Mexico region: Texas to the Florida Straits. In: Lumsden, S.E., Hourigan, T.F., Bruckner, A.W., Dorr, G. (Eds.), The State of Deep Coral Ecosystems of the United States. NOAA Technical Memorandum CRCP-3, Silver Spring, MD, pp. 271-306.

Brooke, S., M.W. Holmes, Young, C.M., 2009. Sediment tolerance of two different morphotypes of the deep-sea coral Lophelia pertusa from the Gulf of Mexico. Marine Ecology Progress Series

$727 \quad 390,137-144$. 
728

729

730

731

732

733

734

735

736

737

738

739

740

741

742

743

744

745

746

747

748

749

750

751

752

753

754

755

756

757

758

759

760

761

762

763

764

765

766

767

768

769

770

Brooke, S.D. (in press) Reproductive biology of deep-sea corals. Ch 10. In: Demopoulos, A.W.J., Ross, S.W., Kellogg, C.A., Morrison, C.L., et al. Deepwater Program: Lophelia II Continuing Ecological Research on Deep-Sea Corals and Deep Reef Habitats in the Gulf of Mexico. U.S. Department of the Interior, U.S. Geological Survey Report Series.

Brooks, G.R., Holmes, C.W., 2011. West Florida Continental Slope. In: Buster, N.A., Holmes, C.W. (Eds.), Gulf of Mexico Origin, Waters, and Biota. Vol. 3, Geology. Texas A\&M Univ. Press, College Station, pp. 129-139.

Brooks, J.M., Fisher, C., Cordes, E., Baums, I., Bernard, B., Church, R., Etnoyer, P., German, C., Goehring, E., McDonald, I., Roberts, H., Shank, T., Warren, D., Welsh, S., Wolff, G., Weaver, D., 2015. Exploration and research of northern Gulf of Mexico deepwater natural and artificial hard-bottom habitats with emphasis on coral communities: Reefs, rigs, and wrecks-"Lophelia II." Final report. U.S. Dept. of the Interior, Bureau of Ocean Energy Management, Gulf of Mexico OCS Region, New Orleans, LA. OCS Study BOEM 2016-021. 628 pp.

Candela, J., Sheinbaum, J., Ochoa, J., Badan, A., 2002. The potential vorticity flux through the Yucatan Channel and the Loop Current in the Gulf of Mexico. Geophysical Research Letters 29, 16-1-16-4.

Continental Shelf Associates, 2007. Characterization of northern Gulf of Mexico deepwater hard bottom communities with emphasis on Lophelia coral. US Department of the Interior, Minerals Management Service, Gulf of Mexico OCS Region, New Orleans, LA OCS Study MMS 2007044, pp.169 + appendices.

Cordes, E.E., McGinley, M.P., Podowski, E.L., Becker, E.L., Lessard-Pilon, S., Viada, S.T., Fisher, C.R., 2008. Coral communities of the deep Gulf of Mexico. Deep-Sea Research I 55, 777-787. Davies, A.J., Duineveld, G.C.A., van Weering, T.C.E., Mienis, F., Quattrini, A.M., Seim, H.E., Bane, J.M., Ross, S.W., 2010. Short-term environmental variability in cold-water coral habitat at Viosca Knoll, Gulf of Mexico. Deep-Sea Research I 57, 199-212.

Davies, A.J., Guinotte, J.M., 2011. Global habitat suitability for framework-forming cold-water corals. Plos One 6, e18483.

Dodds, L.A., Roberts, J.M., Taylor, A.C., Marubini, F., 2007. The cold-water coral Lophelia pertusa (Scleractinia) reveals metabolic tolerance to temperature and dissolved oxygen change. Journal of Experimental Marine Biology and Ecology 349, 205-214.

Doyle, L.J., Holmes, C.W., 1985. Shallow structure, stratigraphy, and carbonate sedimentary processes of West Florida upper continental slope. American Association of Petroleum Geologists Bulletin 69, 1133-1144.

Gardulski, A.F., Mullins, H.T., Weiterman, S., 1990. Carbonate mineral cycles generated by foraminiferal and pteropod response to Pleistocene climate: west Florida ramp slope. Sedimentology 37, 727-743.

Georgian, S.E., Shedd, W., Cordes, E.E., 2014. High-resolution ecological niche modelling of the cold-water coral Lophelia pertusa in the Gulf of Mexico. Marine Ecology Progress Series 506, $145-161$.

Hall-Spencer, J., Rogers, A., Davies, J., Foggo, A., 2007. Deep-sea coral distribution on seamounts, oceanic islands, and continental slopes in the northeast Atlantic. In: George, R.Y., Cairns, S.D. (Eds.), Conservation and Adaptive Management of Seamount and Deepsea Coral Ecosystems. University of Miami, pp.135-146. 
771

772

773

774

775

776

777

778

779

780

781

782

783

784

785

786

787

788

789

790

791

792

793

794

795

796

797

798

799

800

801

802

803

804

805

806

807

808

809

810

811

Hamilton, P., 1990. Deep currents in the Gulf of Mexico. Journal of Physical Oceanography 20, 1087-1104.

He, R., Weisberg, R.H., 2003. A Loop Current intrusion case study on the West Florida shelf. Journal of Physical Oceanography 33, 465-477.

Hebbeln, D., Wienberg, C., Wintersteller, P., Freiwald, A., Becker, M. et al., 2014. Environmental forcing of the Campeche cold-water coral province, southern Gulf of Mexico. Biogeosciences $11,1799-1815$.

Holmes, C.W., 1981. Late Neogene and Quaternary geology of the southwestern Florida shelf and slope. US Department of the Interior Geological Survey, Open-File Rept 81-1029.

Hübscher, C., Dullo, C., Flögel, S., Titschack, J., Schönfeld, J., 2010. Contourite drift evolution and related coral growth in the eastern Gulf of Mexico and its gateways. International Journal of Earth Sciences 99,191-206.

International Hydrographic Organization, 2013. Standardization of undersea feature names: guidelines, proposal form, terminology. ed. 4.1.0, Publication No. B-6. International Hydrographic Organization. Monaco. 38 pp.

Jochens, A.E., DiMarco, S.F., 2008. Physical oceanographic conditions in the deepwater Gulf of Mexico in summer 2000-2002. Deep-Sea Research II 55, 2541-2554.

Larsson, A.I., Järnegren, J., Strömberg, S.M., Dahl, M.P., Lundälv, T., Brooke, S.D., 2014. Embryogenesis and larval biology of the cold-water coral Lophelia pertusa. Plos ONE 9(7), e102222.

Lessard-Pilon, S.A., Podowski, E.L., Cordes, E.E., Fisher, C.R., 2010. Megafauna community composition associated with Lophelia pertusa colonies in the Gulf of Mexico. Deep-Sea Research II 57, 1882-1890.

Lidz, B.H., Reich, C.D., Peterson, R.L., Shinn, E.A., 2006. New maps, new information: coral reefs of the Florida Keys. Journal of Coastal Research 22, 260-282.

Lindberg, W.J., Lockhart, F.D., 1993. Depth-stratified population structure of geryonid crabs in the eastern Gulf of Mexico. Journal of Crustacean Biology 13, 713-722.

Liu, Y., Weisberg, R.H., Hu, C., Kovach, C., Riethmüller, R., 2011. Evolution of the Loop Current system during the Deepwater Horizon oil spill event as observed with drifters and satellites. In: Liu, Y. et al. (Eds.). Monitoring and Modeling the Deepwater Horizon Oil Spill: A RecordBreaking Enterprise. Geophysical Monographs Series 195. American Geophysical Union, Washington, D.C., pp. 91-101.

Lunden, J.J., McNicholl, C.G., Sears, C.R., Morrison, C.L., Cordes, E.E., 2014. Acute survivorship of the deep-sea coral Lophelia pertusa from the Gulf of Mexico under acidification, warming, and deoxygenation. Frontiers Marine Science 1, 1-12.

Martin, A., 2015. Implementation of Coral Habitat Areas of Particular Concern (CHAPCs): South Atlantic Fishery Management Council process. In: Bortone, S.A. (ed.). Interrelationships between corals and fisheries. CRC Marine Biology Series No 16, CRC Press. Boca Raton, FL, pp 39-50.

Maul, G.A., Vukovich, F.M., 1993. The relationship between variations in the Gulf of Mexico Loop Current and Straits of Florida volume transport. Journal of Physical Oceanography 23, 785-796. 
812 Mienis, F., Van Weering, T., De Haas, H., De Stigter, H., Huvenne, V., Wheeler, A., 2006.

813 Carbonate mound development at the SW Rockall Trough margin based on high resolution TOBI and seismic recording. Marine Geology 233, 1-19.

Mienis, F., Duineveld, G.C.A., Davies, A.J., Ross, S.W., Seim, H., Bane, J., van Weering, T.C.E., 2012. The influence of near-bed hydrodynamic conditions on cold-water corals in the Viosca Knoll area, Gulf of Mexico. Deep-Sea Research I 60, 32-45.

Molinari, R.L., 1980. Current variability and its relation to sea-surface topography in the Caribbean Sea and Gulf of Mexico. Marine Geodesy 3, 409-436.

Molinari, R.L., Mayer, D.A., 1982. Current meter observations on the continental slope at two sites in the eastern Gulf of Mexico. Journal of Physical Oceanography 12, 1480-1492.

Molinari, R.L., Morrison, J., 1988. The separation of the Yucatan Current from the Campeche Bank and the intrusion of the Loop Current into the Gulf of Mexico. Journal of Geophysical Research 93, 10645-10654.

Morrison, C.L., Ross, S.W., Nizinski, M.S., Brooke, S., Järnegren, J., Waller, R.G., Johnson, R.L., King, T.L., 2011. Genetic discontinuity among regional populations of Lophelia pertusa in the North Atlantic Ocean. Conservation Genetics 12, 713-729.

Mullins, H.T., Gardulski, A.F., Hinchey, E.J., Hine, A.C., 1988a. The modern carbonate ramp of central West Florida. Journal of Sedimentary Petrologists 58, 273-290.

Mullins, H.T., Gardulski, A.F., Hine, A.C., Melillo, A.J., Wise, S.W., Jr., Applegate, J., 1988b. Three-dimensional sedimentary framework of the carbonate ramp slope of central west Florida: a sequential seismic stratigraphic perspective. Geological Society of America Bulletin 100, 514533.

Newton, C.R., Mullins, H.T., Gardulski, A.F., Hine, A.C., Dix, G.R., 1987. Coral mounds on the West Florida slope: unanswered questions regarding the development of deep-water banks. Palaios 2, 359-367.

Paluszkiewicz, T., Atkinson, L.P., Posmentier, E.S., McClain, C.R., 1983. Observations of a Loop Current frontal eddy intrusion onto the west Florida shelf. Journal of Geophysical Research 88, 9639-9651.

Partyka, M.L., Ross, S.W., Quattrini, A.M., Sedberry, G.R., Birdsong, T.W., Potter, J., 2007. Southeastern United States deep sea corals (SEADESC) initiative: a collaborative effort to characterize areas of habitat-forming deep-sea corals. NOAA Technical Memorandum OAR OER 1. Silver Spring, MD. 176 pp.

Paull, C.K., Neumann, A.C., am Ende, B.A., Ussler, W., III, Rodriguez, N.M., 2000. Lithoherms on the Florida-Hatteras slope. Marine Geology 166, 83-101.

Quattrini, A.M, Ross, S.W., Carlson, M.C.T., Nizinski, M.S., 2012. Megafaunal-habitat associations at a deep-sea coral mound off North Carolina, USA. Marine Biology 159, 1079-1094.

Quattrini, A.M, Etnoyer, P.J., Doughty, C., English, L., Falco, R., Remon, N., Rittinghouse, M., Cordes, E.E., 2014. A phylogenetic approach to octocorals community structure in the deep Gulf of Mexico. Deep-Sea Research II, 99: 92-102.

Reed, J.K., Weaver, D.C., Pomponi, S.A., 2006. Habitat and fauna of deep-water Lophelia pertusa coral reefs off the southeastern U.S.: Blake Plateau, Straits of Florida, and Gulf of Mexico. Bulletin of Marine Science 78, 343-375. 
854

855

856

857

858

859

860

861

862

863

864

865

866

867

868

869

870

871

872

873

874

875

876

877

878

879

880

881

882

883

884

885

886

887

888

889

890

Reed, J.K., Messing, C., Walker, B.K., Brooke, S., Correa, T.B.S., Brouwer, M., et al. (2013) Habitat characterization, distribution, and areal extent of deep-sea coral ecosystems off Florida, southeastern U.S.A. Caribbean Journal of Science 47, 13-30.

Roberts, H., 2011. Surficial geology of the northern Gulf of Mexico continental slope. In: Buster, N.A., Holmes, C.W. (Eds.), Gulf of Mexico Origin, Waters, and Biota. Vol. 3, Geology. Texas A\&M Univ. Press, College Station, pp. 209-228.

Roberts, J.M., Wheeler, A.J., Freiwald, A., Cairns, S.D., 2009. Coldwater corals: the biology and geology of deep-sea coral habitats. Cambridge University Press, Cambridge, 352 pp.

Ross, S.W., Nizinski, M.S. 2007. State of deep coral ecosystems in the U.S. southeast region: Cape Hatteras to southeastern Florida. In: Lumsden, S.E., Hourigan, T.F., Bruckner, A.W., Dorr, G. (Eds.), The State of Deep Coral Ecosystems of the United States. NOAA Technical Memorandum CRCP-3 Silver Spring MD, pp. 233-270.

Ross, S.W., Quattrini, A.M., 2007. The fish fauna associated with deep coral banks off the southeastern United States. Deep-Sea Research I 54, 975-1007.

Ross, S.W., Quattrini, A.M., Roa-Varón, A.Y., McClain, J.P., 2010. Species composition and distributions of mesopelagic fishes over the slope of the north-central Gulf of Mexico. DeepSea Research II 57, 1926-1956.

Ross, S.W., Demopoulos, A.W.J., Kellogg, C.A., Morrison, C.L., Nizinski, M.S., Ames, C.L., Casazza, T.L., Gualtieri, D., Kovacs, K., McClain, J.P., Quattrini, A.M., Roa-Varón, A.Y., Thaler, A.D., 2012. Deepwater Program: Studies of Gulf of Mexico Lower Continental Slope Communities Related to Chemosynthetic and Hard Substrate Habitats. US Geological Survey Open-File Rept. 2012-1032, 301 pp.

Ross, S.W., Brooke, S., Quattrini, A., Rhode, M., Watterson, J.C., 2015. A deep-sea community, including Lophelia pertusa, at unusually shallow depths in the Western North Atlantic Ocean off northeastern Florida. Marine Biology 162, 635-648.

Schroeder, W.W., Brooke, S.D., Olson, J.B., Phaneuf, B., McDonough, J.J., III, Etnoyer, P., 2005. Occurrence of deep-water Lophelia pertusa and Madrepora oculata in the Gulf of Mexico. In: Freiwald, A., Roberts, J.M.(Eds.), Cold-water Corals and Ecosystems. Springer, pp.297-307.

Schroeder, W.W., Brooke, S.D., 2011. Habitat-forming deepwater scleractinian corals in the Gulf of Mexico. In: Buster, N.A., Holmes, C.W. (Eds.), Gulf of Mexico Origin, Waters, and Biota: Vol. 3, Geology. Texas A \& M Press, College Station, TX. pp. 355-363.

Vukovich, F.M., Maul, G.A., 1985. Cyclonic eddies in the eastern Gulf of Mexico. Journal of Physical Oceanography 15, 105-117.

Young, C. M., He, R., Emlet, R.B., Li, Y., Qian, H., Arellano, S.M., Van Gaest, A., Bennett, K.C., Wolf, M., Smart, T.I., Rice, M.E., 2012. Dispersal of deep-sea larvae from the Intra-American Seas: simulations of trajectories using ocean models. International Comparative Biology 52, 483-496. 